\title{
Effects of bariatric surgery on adipokine-induced inflammation and insulin resistance
}

\section{Zeynep Goktas ${ }^{1}$, Naima Moustaid-Moussa ${ }^{1}$, Chwan-Li Shen ${ }^{2}$, Mallory Boylan ${ }^{1}$, Huanbiao Mo ${ }^{3}$ and Shu Wang ${ }^{1 *}$}

${ }^{1}$ Nutritional Sciences Program, College of Human Science, Texas Tech University, Lubbock, TX, USA

${ }^{2}$ Department of Pathology, Texas Tech University Health Sciences Center, Lubbock, TX, USA

${ }^{3}$ Department of Nutrition and Food Sciences, Texas Woman's University, Denton, TX, USA

\section{Edited by:}

Tsuguhito Ota, Kanazawa University, Japan

\section{Reviewed by:}

Undurti Narasimha Das, Undurti N.

Das Life Sciences, USA

Julianne Toohey, University of

California, USA

\section{*Correspondence:}

Shu Wang, Nutritional Science

Program, College of Human Science,

Texas Tech University, P.O. Box:

41240, Lubbock, TX 79409-1240, USA

e-mail: shu.wang@ttu.edu
Over a third of the US population is obese and at high risk for developing type 2 diabetes, insulin resistance, and other metabolic disorders. Obesity is considered a chronic lowgrade inflammatory condition that is primarily attributed to expansion and inflammation of adipose tissues. Indeed, adipocytes produce and secrete numerous proinflammatory and anti-inflammatory cytokines known as adipokines. When the balance of these adipokines is shifted toward higher production of proinflammatory factors, local inflammation within adipose tissues and subsequently systemic inflammation occur. These adipokines including leptin, visfatin, resistin, apelin, vaspin, and retinol binding protein-4 can regulate inflammatory responses and contribute to the pathogenesis of diabetes. These effects are mediated by key inflammatory signaling molecules including activated serine kinases such as c-Jun $\mathrm{N}$-terminal kinase and serine kinases inhibitor $\kappa \mathrm{B}$ kinase and insulin signaling molecules including insulin receptor substrates, protein kinase B (PKB, also known as Akt), and nuclear factor kappa B. Bariatric surgery can decrease body weight and improve insulin resistance in morbidly obese subjects. However, despite reports suggesting reduced inflammation and weight-independent effects of bariatric surgery on glucose metabolism, mechanisms behind such improvements are not yet well understood. This review article focuses on some of these novel adipokines and discusses their changes after bariatric surgery and their relationship to insulin resistance, fat mass, inflammation, and glucose homeostasis.

Keywords: bariatric surgery, inflammation, obesity, insulin resistance, adipokines

\section{INTRODUCTION}

Obesity refers to excess fat mass or adiposity, and is typically defined as a body mass index (BMI) over $30 \mathrm{~kg} / \mathrm{m}^{2}$ or a waist circumference greater than $94 \mathrm{~cm}$ for men and $80 \mathrm{~cm}$ for women (Nash et al., 2008). It is a complex multifactorial disease that is positively associated with increased risk and onset of numerous chronic diseases including cardiovascular disease and Type 2 diabetes (Sjostrom et al., 2004). According to the World Health Organization report, one billion of the world's adult population is overweight and 300 million of them are obese (Mushtaq et al., 2011). One of three adults is obese in the United States (Bhattacharya and Sood, 2011).

The first recommended treatment option for obesity is a lowcalorie diet and regular physical activity. However, these lifestyle interventions have low compliance in general and limited effectiveness in severely obese people (Hell and Miller, 2002; Yermilov et al., 2009). Bariatric surgery has emerged as the approach of choice for weight loss among morbidly obese adults with a BMI over $40 \mathrm{~kg} / \mathrm{m}^{2}$ or those with a BMI over $35 \mathrm{~kg} / \mathrm{m}^{2}$ and existing metabolic risk factors such as hypertension, diabetes, or hypercholesterolemia (Sjostrom et al., 2004; Kulick et al., 2010).

Recent research has established that obesity is a chronic lowgrade inflammatory condition (Herder et al., 2007; Liu et al., 2007; Amati et al., 2010; Balistreri et al., 2010; Park et al., 2010;
Thompson et al., 2011). Following bariatric surgery, patients usually experience approximately $30 \%$ weight loss as well as decreased overall inflammatory responses (Compher and Badellino, 2008). Concomitantly, there are beneficial changes such as improved insulin resistance, reduced cardiovascular risk, and decreased oxidative stress that are achieved through multiple pathways related to systemic and adipocyte inflammation and adipocytederived cytokines (Cancello et al., 2005; Holdstock et al., 2005; Mattar et al., 2005; Vazquez et al., 2005; Poitou et al., 2006; Iannelli et al., 2009, 2010; Boesing et al., 2010; Butner et al., 2010; Hofso et al., 2010; Joao Cabrera et al., 2010; Murri et al., 2010; Kalupahana et al., 2011, 2012).

\section{BARIATRIC SURGERY}

Different types of bariatric surgeries are used for reducing body weight with various success rates (Franco et al., 2011). In Rouxen-Y gastric bypass, the stomach is divided into two parts: a small proximal pouch (15-20 ml) and a large distal pouch (Figure 1A). The small proximal pouch is attached to the proximal jejunum, bypassing the large distal gastric pouch and duodenum (Jaunoo and Southall, 2010). In this procedure energy intake is restricted by the small volume of the stomach pouch (Arceo-Olaiz et al., 2008; Yan et al., 2008). Moreover, bypassing the duodenum decreases the digestion and absorption of food. In vertical banded gastroplasty, 


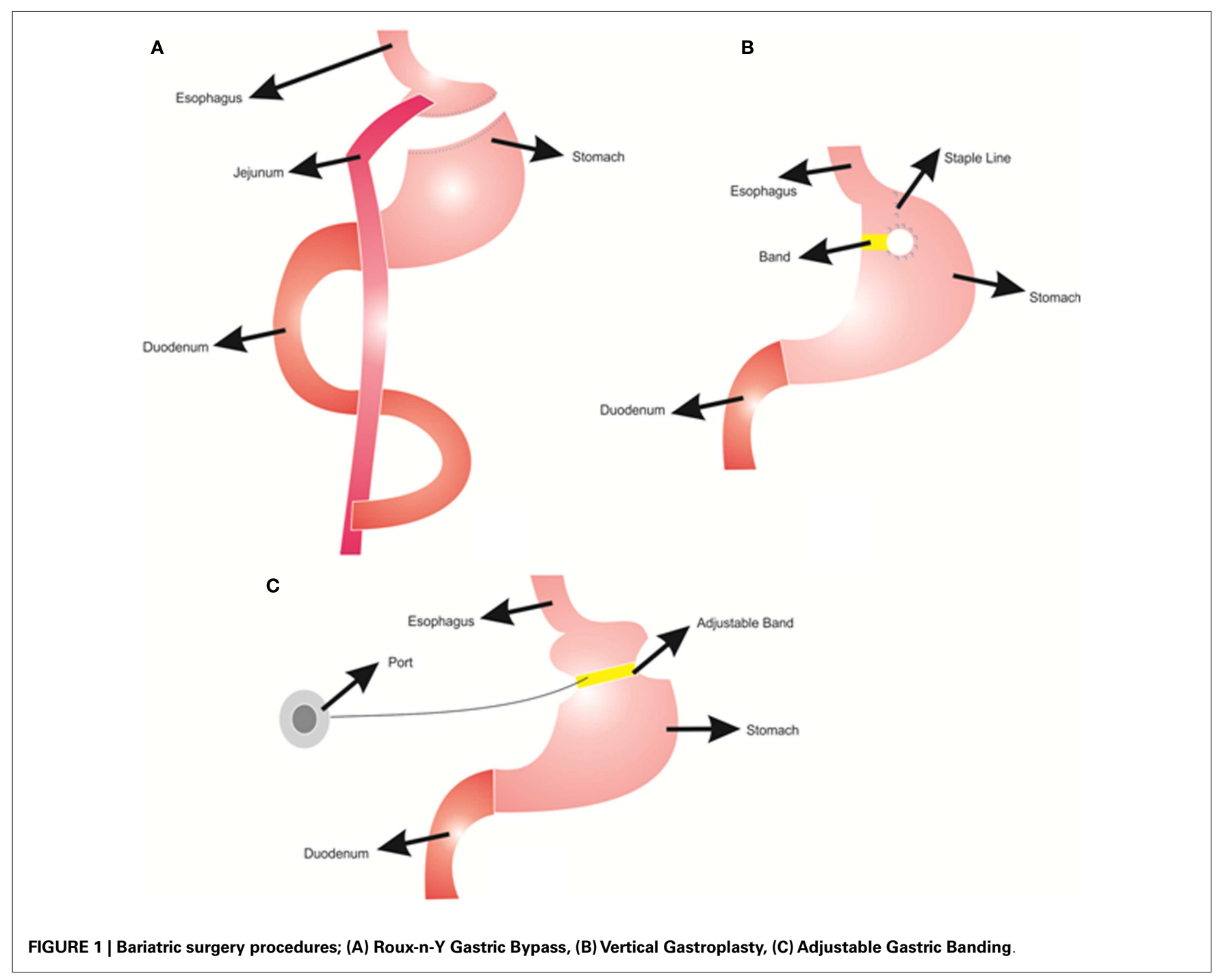

the proximal stomach is stapled vertically, allowing food draining from the proximal pouch to the distal pouch with the outlet reinforced with a mesh collar to prevent the enlargement of proximal pouch and staple line failures (Figure 1B) (Franco et al., 2011). This procedure decreases the energy intake due to reduced stomach size. However, staple line failures are very common problems that may lead to regaining of the lost weight (van Hout et al., 2007). In gastric banding, a cuff band is used to section the stomach into proximal and distal parts (Figure 1C). In the adjustable form, there is an inflatable balloon in the cuff band. A reservoir can be placed under the skin and band size can be adjusted by inflating the balloon from this reservoir (Camerini et al., 2004; Spivak et al., 2005; Picot et al., 2009). The Roux-en-Y gastric bypass procedure is more effective for weight loss than the vertical banded gastroplasty and the adjustable gastric banding (Picot et al., 2009).

\section{INFLAMMATION IN OBESITY}

Adipose tissue is considered as an endocrine organ, which consists of $<50 \%$ adipocytes and $>50 \%$ stromal vascular fraction that contains blood cells, endothelial cells, adipose-tissue precursors and stem cells, macrophages, and other immune cells (Wang and Nakayama, 2010). As an endocrine organ, the adiposetissue produces and secretes several hormones and cytokines that play important roles in carbohydrate and lipid metabolism, inflammation, blood coagulation, as well as satiety, and hunger signaling (Hajer et al., 2008; Qasim et al., 2008; Wang and Nakayama, 2010). These cytokines, also known as adipocytokines or adipokines, are either secreted by adipocytes and/or by the stromal vascular fraction, especially macrophages, as summarized in Table 1 (Wang and Nakayama, 2010; Gomez-Illan et al., 2012; Kalupahana et al., 2012). Adipokines can function as classical cytokines, growth factors and proteins that are involved in blood pressure regulation, vascular homeostasis, and lipid and glucose metabolisms (Trayhurn, 2007).

In obesity, expansion of adipose-tissue causes hypoxia and stress, leading to necrosis of adipocytes. More than $90 \%$ of macrophages in white adipose tissues of animals are localized to dead adipocytes. The "Crown-Like Structure" (Yudkin, 2007) describes necrotic cells with impaired cell integrity and lipid droplets (Mosser and Edwards, 2008) and the surrounding 


\begin{tabular}{lcl}
$\begin{array}{l}\text { Table } 1 \text { | Obesity-associated changes in the levels of common } \\
\text { cytokines secreted by adipocytes and macrophages. }\end{array}$ \\
\hline Cytokines & Changes & Reference \\
\hline ADIPOCYTE SECRETIONS & \\
Leptin & $\uparrow$ & Oswal and Yeo (2010) \\
Adinopectin & $\downarrow$ & Asayama et al. (2003) \\
Visfatin & $\uparrow$ & Sandeep et al. (2007a) \\
Vaspin & $\uparrow$ & Li et al. (2008) \\
Apelin & $\uparrow$ & Boucher et al. (2005) \\
FABP-4 & $\downarrow$ & Queipo-Ortuno et al. (2012) \\
Perilipin & $\downarrow$ & Wang et al. (2003) \\
RBP-4 & $\uparrow$ & Wolf (2007) \\
Resistin & $\uparrow$ & Piestrzeniewicz et al. (2008) \\
Lipocalin 2 & $\uparrow$ & Catalan et al. (2009) \\
MACROPHAGE SECRETIONS & \\
IL-6 & $\uparrow$ & Cesari et al. (2005) \\
TNF- $\alpha$ & $\uparrow$ & Tzanavari et al. (2010) \\
HGF & $\uparrow$ & Bell et al. (2006) \\
IL-10 & $\downarrow$ & Blüher et al. (2005) \\
IL-18 & $\uparrow$ & Leick et al. (2007) \\
PAI-1 & $\uparrow$ & Cesari et al. (2005) \\
CRP & $\uparrow$ & Park et al. (2005) \\
MCP-1 & Panee (2012) \\
VEGF & Garcia de la Torre et al. (2008) \\
\hline
\end{tabular}

FABP-4, Fatty Acid Binding Protein-4; RBP-4, Retinol Binding Protein-4; IL-6, Interleukin 6; TNF- , Tumor necrosis factor-alpha; HGF, Hepatocyte Growth Factor; IL-10, Interleukin 10; IL-18, Interleukin 18; PAI-1, Plasminogen activator inhibitor-1; CRP, C-reactive Protein; MCP-1, Monocyte Chemoattractant Protein-1; VEGF, Vascular Endothelial Growth Factor.

macrophages that serve as scavengers of cell debris and lipid droplets in the necrotic cells.

There are two types of macrophages in white adipose tissues: proinflammatory M1 type and anti-inflammatory M2 type (Rull et al., 2010). M1 type macrophages are mainly recruited and induced by proinflammatory cytokines produced by expanded adipose tissue. After M1 type macrophages infiltrate into the adipose tissue, they secrete more proinflammatory cytokines and produce reactive oxygen species (ROS), which can recruit more macrophages and amplify the inflammatory response. M2 type macrophages are adipose-tissue resident macrophages (Rull et al., 2010). These macrophages are also called as alternatively activated macrophages because they are activated by interleukin (IL)-4. M2 type macrophages secrete anti-inflammatory cytokines and have mannose receptors, scavenger receptors and distinct integrins, which lead to anti-inflammatory functions (Mosser and Edwards, 2008; Rull et al., 2010). With stress and hypoxia in expanded adipose-tissue during obesity, M2 type macrophages lose their IL-4 receptor expression and IL-4-mediated anti-inflammatory functions, and instead are differentiated into M1 type proinflammatory macrophages (Rull et al., 2010). Besides IL-4, decreased expression of IL-10, Ym1, Arginase-1, and increased expression of tumor necrosis factor-alpha (TNF- $\alpha$ ) and inducible nitric oxide synthetase (iNOS) induce the switch of adipose-tissue macrophages from a M2 to M1 phenotype.
This switch increases the number of proinflammatory macrophages, resulting in increased production of cytokines and chemokines including monocyte chemoattractant protein (MCP)-1, MCP-2, Regulated upon Activation, Normal T cell Expressed and Secreted (RANTES), and chemokine receptors like CCR2 and CCR5 (Wang and Nakayama, 2010). These inflammatory chemokines further increase macrophage infiltration to the adipose tissue (Malavazos et al., 2005; Trayhurn, 2005).

Kanda et al. found that macrophages and endothelial cells in rat adipose tissue can secrete MCP-1. This chemokine and its receptor CCR2 direct the migration of monocytes into the adipose tissue. Subsequent exposure of the monocytes to macrophage colony-stimulating factor causes differentiation to macrophages, which can secrete more MCP-1 (Kanda et al., 2006). In another study, obese subjects had significantly higher plasma MCP-1 levels than lean subjects, and increased plasma MCP-1 levels were positively associated with insulin resistance (Catalan et al., 2007). In expanded adipose tissue, M1 type macrophages secrete not only MCP-1, but also other proinflammatory cytokines including TNF$\alpha$, IL-6, IL-1, IL-1 $\beta$, and IL-8, which can amplify inflammatory responses (Coppack, 2001; Zeyda and Stulnig, 2009).

\section{THE ROLES OF INFLAMMATION ON INSULIN SIGNALING}

The major regulators in the insulin signaling pathway are insulin receptor substrates (IRSs). The binding of insulin to its receptor leads to tyrosine phosphorylation of the receptor. This phosphorylation is recognized by the IRS family that has 6 member proteins, IRS1 to IRS6. IRS1 plays an important role in transmitting signals from the insulin receptor on cell membrane to intracellular phosphatidiylinositol-3-kinase (PI3K)/Akt and extracellular signal-regulated kinases (Erk)/mitogen-activated protein kinase (MAPK) pathways (Cai et al., 2003; Tarantino and Caputi, 2011). Under normal circumstance, the binding of insulin to the insulin receptor induces a conformational change of the receptor, which leads to autophosphorylation of specific tyrosine residues in the cytoplasmic domains of the receptor and further recruitment of adapter proteins IRSs (Nieto-Vazquez et al., 2008). After interacting with IRSs, PI3K is activated. PI3K lipid products can further recruit and activate Akt through phosphorylation on threonine 308 (T308) (Nieto-Vazquez et al., 2008). Akt is an important component of insulin signaling pathways. IRS1 tyrosine phosphorylation leads to a second wave of phosphorylation in the Akt protein. Phosphorylated Akt then initiates more phosphorylation reactions and eventually leads to glucose uptake, glycogen synthesis, protein synthesis, cell survival and gene transcriptions (Siddle, 2011) (Figure 2). Tyrosine phosphorylation is required for IRS1 activation and insulin sensitization, which are blocked by serine phosphorylation on IRS1.

Increased production of TNF- $\alpha$ in expanded adipose-tissue decreases insulin sensitivity (Fantuzzi, 2008). TNF- $\alpha$ binds to TNF receptor-1 (TNFR1) and activates serine kinases including c-Jun N-terminal kinase (JNK), serine kinases inhibitor $\kappa \mathrm{B}$ kinase (IKK) and S6 kinase (S6K). These serine kinase can cause serine phosphorylation of IRS1, block activation of downstream signaling molecules, and further decrease insulin sensitivity (Fain, 2010) (Figure 2). JNK and IKK are important components of the activator protein-1 (AP-1) and nuclear factor kappa B (NF-kB) 


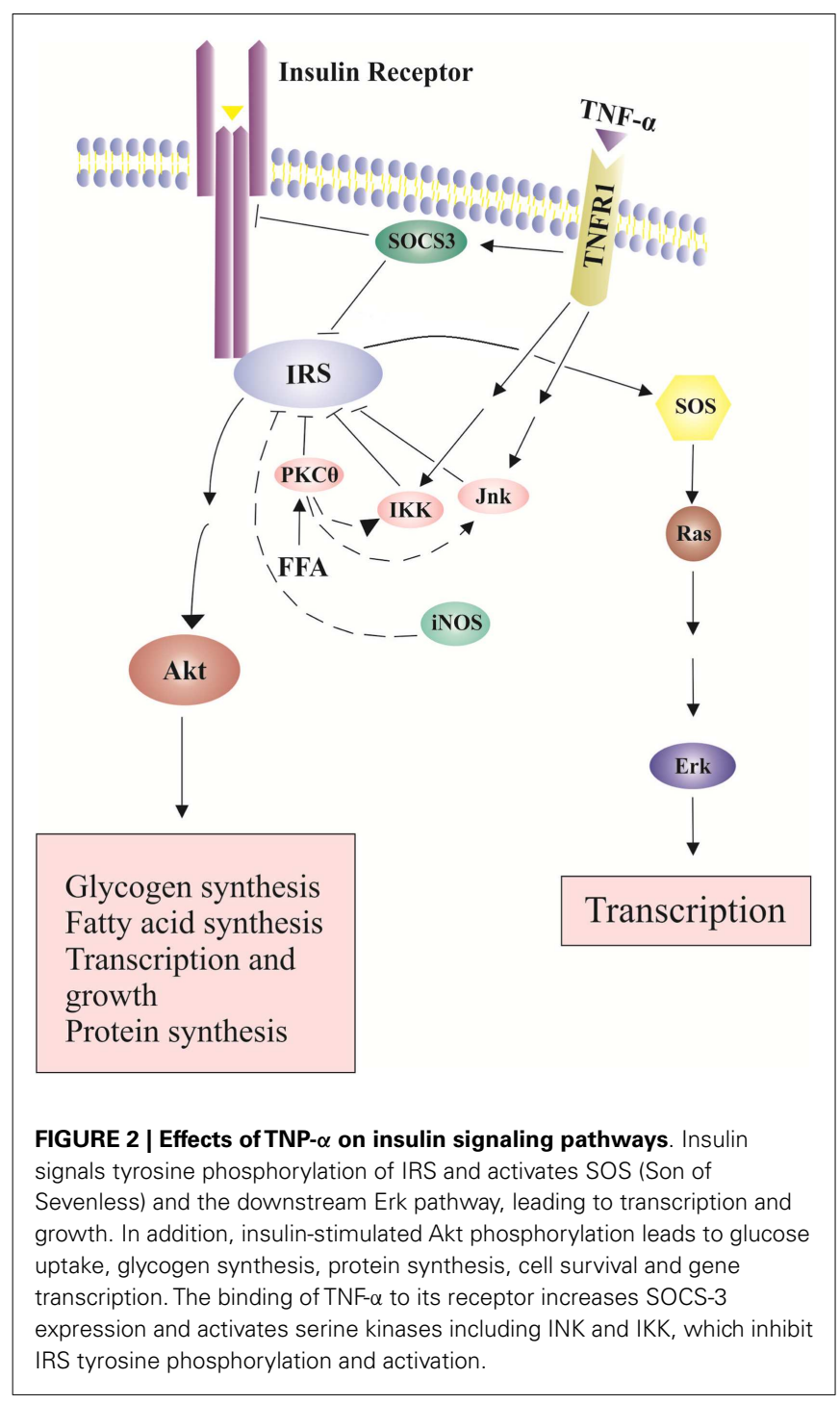

cascade, respectively (Dhanasekaran and Johnson, 2007; Israel, 2010). NF-kB cascade includes a series of transcription factors that are sequestered by inhibitor of kappa $\mathrm{B}(\mathrm{IkB})$ proteins in the cytoplasm under normal conditions. IkB kinase (IKK), an important kinase in the NF-kB cascade, can phosphorylate and inactivate IkB proteins, and activate NF-kB (Israel, 2010). Proinflammatory cytokines like TNF- $\alpha$ can bind to its cell membrane receptor (TNFR1), activate IKK, further phosphorylate and inactivate IkB proteins (Israel, 2010). Subsequently, active NF-kB can translocate into the nucleus, bind on the promoter regions of cytokine genes, and stimulate proinflammatory cytokine expression (Ndisang, 2010). TNF- $\alpha$ also increases the expression of cytokine signaling (SOCS)-1 and SOCS-3 proteins, which can inhibit tyrosine phosphorylation of IRS1 and induce ubiqutinylation and degradation of IRS1 (Figure 2). The expression of SOCS-1 and SOCS-3 is also stimulated by IL-6. SOCS-3 blunts hepatocyte insulin signaling by binding to insulin receptors and leading to degradation of IRS proteins (Rasouli and Kern, 2008; Balistreri et al., 2010). In the absence of SOCS-3, IL-6 can have somewhat anti-inflammatory properties
(Johnston and O'Shea, 2003). Increased plasma IL-6 concentrations are associated with insulin resistance (Charles et al., 2011). In addition, nitric oxide (NO), an endogenous signaling molecule produced by iNOS, can reduce Akt activity (Rasouli and Kern, 2008).

TNF- $\alpha$ and IL- 6 can also alter the protein expression of peroxisome proliferator-activated receptor (PPAR)- $\gamma$ in adipocytes (Leff et al., 2004; Tilg and Moschen, 2008; Zhou et al., 2008; Fernandez-Veledo et al., 2009). PPAR $\gamma$ is an anti-inflammatory nuclear protein with insulin sensitizing functions (FernandezVeledo et al., 2009). PPAR $\gamma$ blunts inflammatory responses and stimulates a switch of adipose-tissue macrophages from a M1 to M2 phenotype (Zeyda and Stulnig, 2009). PPAR $\gamma$ can inhibit the NF-kB signaling pathway, which is an insulin desensitizing pathway because it activates serine kinases and up-regulates the production of proinflammatory cytokines like TNF- $\alpha$ and IL-6 (Sidhu et al., 2003). However, JNK and IKK serine kinases can induce NF-kB activation and further increase TNF- $\alpha$ and IL-6 production, resulting in the suppression of PPAR $\gamma$ in adipocytes (O'Rourke, 2009). This suppression blunts PPAR $\gamma$ insulin sensitizing functions and leads to insulin resistance via the up-regulated NF-kB signaling pathway (Sidhu et al., 2003). Other than the serine kinases, saturated fatty acids can activate the NF-kB signaling pathway by binding to toll-like receptor 2 (TLR2) and 4 (TLR4) in adipocytes. TLR2 and TLR4 are important receptors of the immune system. Saturated fatty acids can bind to TLRs as their ligands and increase proinflammatory cytokine production (Jagannathan et al., 2010). Activation of TLR2 and TLR4 eventually contributes to insulin resistance via activating the NF-kB signaling pathway and increasing proinflammatory cytokine production (Monteiro and Azevedo, 2010).

C-reactive protein (CRP), an acute phase protein, is primarily synthesized in the liver and plays an important role in regulating the innate immune system (Eisenhardt et al., 2009). CRP aggravates the inflammatory status and leads to systemic inflammation (Wang and Nakayama, 2010). Plasma CRP levels are correlated with circulating levels of other inflammatory biomarkers (Kones, 2010). There is also a strong positive correlation between plasma CRP levels and insulin resistance (Pradhan et al., 2003; Pfutzner and Forst, 2006). Hepatic synthesis of CRP is driven at the transcriptional level by IL-6, which is mainly secreted by macrophages, T cells, and adipocytes (Pfutzner and Forst, 2006; Pfutzner et al., 2006). Since CRP mRNA levels rise in expanded adipose tissue, it has been proposed that adipose cells also have some ability to synthesize CRP (Memoli et al., 2007).

\section{THE CHANGES OF NOVEL ADIPOKINES AFTER BARIATRIC SURGERY AND THEIR RELATIONSHIP TO INSULIN RESISTANCE}

Other than the classic cytokines and chemokines such as TNF$\alpha$, MCP-1, and IL- 6 , adipocytes also secrete leptin, adiponectin, visfatin, resistin, omentin, apelin, vaspin, perilipin, adipsin, and retinol binding protein-4. All these adipokines can contribute to systemic inflammation and pathogenesis of obesity-associated complications (Balistreri et al., 2010). An evidence-based review by Spector and Shikora (2010) attributed the bariatric surgeryinduced insulin sensitization to surgery-specific, metabolic effects 
on glucose homeostasis that are independent of weight loss. However, the underlying mechanisms are not yet understood. This review article focuses on novel adipokines including visfatin, resistin, apelin, vaspin, and retinol binding protein-4 (RBP-4) and addresses their changes after bariatric surgery and their relationship to insulin resistance (Table 2).

\section{VISFATIN}

Visfatin is produced and secreted mainly by adipocytes in visceral adipose tissue (Tokunaga et al., 2008). Visfatin is also produced by a variety of cells including lymphocytes, monocytes, neutrophils, and hepatocytes (Kukla et al., 2011). This peptide adipokine produces insulin-mimetic effects by binding to the insulin receptor. The binding and further activation of the insulin signaling pathway can stimulate glucose uptake and increase insulin sensitivity (Fukuhara et al., 2005; Tilg and Moschen, 2006; Sun et al., 2007; Tokunaga et al., 2008; Fain, 2010). Visfatin and insulin bind to the different sites of the same insulin receptor (Tilg and Moschen, 2006). This difference in binding sites allows visfatin and insulin to work non-competitively. Similar to insulin, visfatin stimulates the phosphorylation of IRS1, IRS2, PI3K binding to IRSs, and activation of Akt and further promotes insulin sensitivity (Fukuhara et al., 2005; Adya et al., 2008a; Tan et al., 2009). Some studies suggested that NF-kB, JNK, and AP-1 upregulate visfatin production (Kim et al., 2007, 2008; Adya et al., 2008b; McGee et al., 2011).

There are many inconclusive data regarding the relationship between serum visfatin levels and body fat percentage or insulin resistance. Several studies suggest that blood visfatin levels are significantly related to type 2 diabetes or insulin resistance, but not to body fat percentage or BMI (Sandeep et al., 2007a; Palin et al., 2008; Retnakaran et al., 2008). One study compared plasma visfatin levels between type 2 diabetes subjects and non-diabetic healthy subjects and found that type 2 diabetes subjects had higher serum visfatin levels than non-diabetic healthy subjects (Sandeep et al., 2007b). However, this positive correlation between serum visfatin levels and diabetes status was no longer significant after adjusting for anthropometrics such as BMI and waist circumference (Dogru et al., 2007; Alghasham and Barakat, 2008; Retnakaran et al., 2008). In contrast, other studies reported that serum visfatin

Table 2 |The origin and roles of some novel adipokines in inflammation and insulin signaling and their responses to obesity, insulin resistance and bariatric surgery.

\begin{tabular}{|c|c|c|c|c|c|c|}
\hline Adipokine & Origin & $\begin{array}{l}\text { Roles in } \\
\text { inflammation }\end{array}$ & $\begin{array}{l}\text { Roles in } \\
\text { insulin signaling }\end{array}$ & $\begin{array}{l}\text { Response to } \\
\text { obesity }\end{array}$ & $\begin{array}{l}\text { Response to } \\
\text { insulin } \\
\text { resistance }\end{array}$ & $\begin{array}{l}\text { Response to } \\
\text { bariatric surgery }\end{array}$ \\
\hline Resistin & $\begin{array}{l}\text { Visceral adipose } \\
\text { tissue }\end{array}$ & $\begin{array}{l}\text { Proinflammatory } \\
\text { effects via activating } \\
\text { NF-kB (Maenhaut } \\
\text { and Van de Voorde, } \\
\text { 2011) }\end{array}$ & $\begin{array}{l}\text { Insulin desensitizing } \\
\text { effects via activating } \\
\text { NF-kB and SOCS-3 } \\
\text { (Steppan et al., 2005) }\end{array}$ & $\begin{array}{l}\text { Elevated (Moschen } \\
\text { et al., 2009) }\end{array}$ & $\begin{array}{l}\text { Inconclusive (labal } \\
\text { et al., 2005, Sentinelli } \\
\text { et al., 2002; Lee et al., } \\
\text { 2003) }\end{array}$ & $\begin{array}{l}\text { Inconclusive (labal } \\
\text { et al., 2005; } \\
\text { Marantos et al., } \\
\text { 2011) }\end{array}$ \\
\hline Vaspin & $\begin{array}{l}\text { Visceral adipose } \\
\text { tissue, } \\
\text { subcutaneous } \\
\text { adipose tissue }\end{array}$ & Unknown & $\begin{array}{l}\text { Insulin sensitizing } \\
\text { effects (Kloting et al., } \\
\text { 2006) }\end{array}$ & $\begin{array}{l}\text { Elevated (Youn et al., } \\
\text { 2008; Chang et al., } \\
\text { 2010) }\end{array}$ & $\begin{array}{l}\text { Elevated (Ye et al., } \\
\text { 2009; Kempf et al., } \\
\text { 2010) }\end{array}$ & $\begin{array}{l}\text { Decreased (Chang } \\
\text { et al., 2010; } \\
\text { Handisurya et al., } \\
\text { 2010) }\end{array}$ \\
\hline RBP-4 & $\begin{array}{l}\text { Adipose tissue, } \\
\text { liver }\end{array}$ & Unknown & $\begin{array}{l}\text { Inhibits PI3K and IRS } \\
\text { activation, and GLUT4 } \\
\text { protein expression } \\
\text { Wolf, 2007; Esteve } \\
\text { et al., 2009) }\end{array}$ & $\begin{array}{l}\text { Mostly elevated } \\
\text { Yao-Borengasser } \\
\text { et al., 2007; Bajzova } \\
\text { et al., 2008; } \\
\text { Gomez-Ambrosi } \\
\text { et al., 2008) }\end{array}$ & $\begin{array}{l}\text { Elevated (Graham } \\
\text { et al., 2006; Esteve } \\
\text { et al., 2009) }\end{array}$ & $\begin{array}{l}\text { Decreased (Janke } \\
\text { et al., 2006; von } \\
\text { Eynatten et al., 2007; } \\
\text { Bajzova et al., 2008) }\end{array}$ \\
\hline
\end{tabular}


levels were significantly associated with obesity even after adjusting for age, sex, and diabetes (Fukuhara et al., 2005; Sandeep et al., 2007b). Moreover, serum visfatin levels were more associated with visceral fat mass than subcutaneous fat mass and appear to vary according to the body fat composition (Sun et al., 2007; BotellaCarretero et al., 2008). More studies are required to investigate their relationship.

Surprisingly, plasma visfatin concentrations were elevated after bariatric surgery (Krzyzanowska et al., 2006; Garcia-Fuentes et al., 2007; Botella-Carretero et al., 2008; Friebe et al., 2011). In one study of 53 severely obese persons who underwent biliopancreatic diversion $(n=38)$ and gastric bypass $(n=15)$, plasma visfatin levels were significantly increased 7 months after the surgery, and they were positively correlated with the percentage of waist circumference reduction (Garcia-Fuentes et al., 2007). In another report, there was an almost 50\% increase in plasma visfatin levels postcompared to pre-biliopancreatic or laparoscopic bariatric surgery. In this study, multiple regression analysis showed that weight loss, diabetic status, and waist circumference changes were the main contributors to the increased serum visfatin levels (BotellaCarretero et al., 2008). Overall, these results indicate that plasma visfatin levels tend to be increased after weight loss surgeries (Garcia-Fuentes et al., 2007; Botella-Carretero et al., 2008). Given the well documented insulin-mimetic effect visfatin, the reason for the increased visfatin levels after weight loss is unclear, but may indicate a role for visfatin in improved insulin sensitivity after weight loss surgeries.

\section{RESISTIN}

Resistin is mainly secreted by adipocytes and macrophages found in visceral adipose tissue. Increased plasma resistin levels lead to over-production of glucose from the liver and inhibit preadipocyte differentiation; however the precise mechanisms are still unclear (Steppan et al., 2001; Steppan and Lazar, 2002; Wolf, 2004). In rats, resistin induces severe hepatic insulin resistance and increases glucose production (Piestrzeniewicz et al., 2008). In human studies the role of resistin in insulin resistance and glucose metabolism is inconclusive (Lee et al., 2003; Qasim et al., 2008). The proinflammatory effects of resistin were attributed to its ability to activate NF-kB signaling pathway and subsequently increase the production of proinflammatory cytokines including TNF- $\alpha$ and IL-6, both of which can impair insulin signaling pathways and lead to insulin resistance (Zeyda and Stulnig, 2009; Singla et al., 2010; Maenhaut and Van de Voorde, 2011). In addition, resistin can activate SOCS-3 protein, which can lead to insulin resistance (Steppan et al., 2005). Although some studies suggest a relationship between resistin and glucose metabolism, others disagree (Sentinelli et al., 2002; Lee et al., 2003; Iqbal et al., 2005). Moreover, several studies reported that increased plasma resistin levels were associated with increased BMI (Filkova et al., 2009; Moschen et al., 2009).

Effects of bariatric surgery on plasma resistin levels are inconclusive. Some studies found that plasma resistin levels were significantly decreased 12 months after bariatric surgery with $>10 \%$ loss of the excess body weight (Edwards et al., 2010; JankiewiczWika et al., 2011; Marantos et al., 2011). These studies also reported that plasma resistin levels were positively correlated with insulin resistance and glucose intolerance (Moschen et al., 2009; De Luis et al., 2010; Jankiewicz-Wika et al., 2011; Marantos et al., 2011). Other studies showed no difference in plasma resistin levels after significant weight loss caused by bariatric surgery (Wolfe et al., 2004; Iqbal et al., 2005). More studies are required to investigate the relationship between plasma resistin levels and weight loss.

\section{APELIN}

Apelin is a recently discovered peptide that is secreted by diverse tissues including central nervous system, adipose, and many other peripheral tissues, such as heart, kidneys, liver, and brain. Apelin is a binding ligand for the orphan G-protein-coupled receptor APJ (Yamamoto et al., 2011). A common 77-amino-acid precursor produces three bioactive apelin, which contain 13 amino acids (apelin-13), 17 amino acids (apelin-17), or 36 amino acids (apelin36), respectively (Beltowski, 2006; Reinehr et al., 2011). Animal studies showed that apelin-deficient mice are insulin resistant and develop hyperinsulinemia, which can be reversed by administration of exogenous apelin (Yue et al., 2010). Administration of apelin to diabetic $(\mathrm{db} / \mathrm{db})$ obese mice can increase glucose uptake and elevate insulin sensitivity (Dray et al., 2008; Yue et al., 2010). Apelin stimulates PI3K/Akt phosphorylation-dependent GLUT 4 translocation, therefore increases glucose uptake by adipocytes (Lee et al., 2006; Zhu et al., 2011). Furthermore, apelin secretion can activate AMP-activated protein kinase (AMPK) pathway and leading to an insulin sensitizing effect (Kadoglou et al., 2010; Attane et al., 2011).

Apelin expression and secretion are increased during adipocyte differentiation and are regulated nutritionally and hormonally (Boucher et al., 2005; Dray et al., 2008). Type 2 diabetes subjects have significantly higher plasma apelin levels than non-diabetic healthy subjects. The increase in plasma apelin levels may be a result of compensatory response to insulin resistance (Boucher et al., 2005; Soriguer et al., 2009; Dray et al., 2010). Obese subjects have significantly higher plasma apelin levels than lean subjects (Boucher et al., 2005; Heinonen et al., 2005; Castan-Laurell et al., 2011). Soriguer et al. (2009) demonstrated that the plasma apelin levels were increased only in obese and diabetic subjects, not in obese and non-diabetic subjects, as compared with control subjects. This indicates that obesity and body fat mass may not be the main factors altering circulating apelin levels (Boucher et al., 2005), and insulin resistance may be more important than obesity in increasing plasma apelin levels in humans. Although there is a strong positive correlation between plasma apelin levels and TNF- $\alpha$ expression in expanded adipose tissue, the role of apelin in regulating inflammatory response is still not clear (Boucher et al., 2005; Daviaud et al., 2006).

Plasma apelin levels can vary according to the diabetic status after weight loss following the bariatric surgery. In a study, diabetic morbidly obese patients had significantly higher plasma apelin levels than non-diabetic non-obese healthy subjects. After bariatric surgery, plasma apelin levels in morbidly obese subjects with impaired blood glucose were significantly decreased (Soriguer et al., 2009). Krist et al. (2013) also demonstrated that bariatric surgery dramatically decreased the apelin expression in adipose tissues and serum apelin levels, which significantly correlated 
with improved insulin sensitivity. This correlation is independent of BMI changes. More studies are required to investigate the underlying mechanisms.

\section{VASPIN}

Vaspin is a member of the serine protease inhibitor family and is also known as visceral adipose-tissue derived serpin. But human subcutaneous adipose tissue, liver, stomach, and rodent hypothalamus also express vaspin (Lee et al., 2011). Vaspin is also expressed in adipose tissues in Otsuka Long-Evans Tokushima rats, which are used as an animal model for studying type 2 diabetes (ElMesallamy et al., 2011). Studies suggest that vaspin may have important roles in obesity and insulin resistance (Li et al., 2011). Administration of vaspin to obese mice improved glucose tolerance and elevates insulin sensitivity (Hida et al., 2005; Wada, 2008). However, the underlying mechanisms of improving insulin sensitivity are not known.

Some studies demonstrate that diabetic subjects have higher serum vaspin levels than non-diabetic subjects (Ye et al., 2009; Kempf et al., 2010). Lean subjects have lower serum vaspin levels than overweight subjects (Suleymanoglu et al., 2009). Others reported a positive association between blood vaspin levels and BMI in obesity (Youn et al., 2008; Chang et al., 2010; Bluher, 2012). Blood vaspin levels and BMI correlation is strong in type 2 diabetes or insulin resistant patients. This indicates that obesity-induced insulin resistance may be more important than BMI in regulating circulating vaspin levels (Youn et al., 2008; Chang et al., 2010; Kempf et al., 2010). Since vaspin can improve glucose tolerance and insulin sensitivity, the increase in plasma vaspin levels may be a result of compensatory response to insulin resistance.

Weight loss decreases plasma vaspin levels in humans (Kloting et al., 2006; Li et al., 2008; Youn et al., 2008). Weight loss after bariatric surgery significantly decreases plasma vaspin levels, which also correlates with decreased plasma insulin levels and improved insulin sensitivity (Chang et al., 2010; Handisurya et al., 2010). This decrease might be a compensatory mechanism associated with weight loss and insulin sensitivity. Even though these findings suggest that vaspin may have some roles in regulating glucose metabolism and insulin signaling pathways, the mechanisms are not yet understood (Kloting et al., 2006; Youn et al., 2008).

\section{RETINOL BINDING PROTEIN-4}

Retinol binding protein-4 (RBP-4) is secreted predominantly by adipocytes and hepatocytes. In plasma, RBP-4 is the carrier protein of retinol and appears to relate to glucose metabolism and insulin sensitivity (Esteve et al., 2009). Increased RBP-4 levels lead to reduced glucose uptake by muscle cells through inhibiting PI3K signaling pathway and serine phosphorylation of IRS1 (Wolf, 2007), followed by decreased insulin sensitivity. Some studies demonstrated an inverse correlation between glucose transporter 4 (GLUT4) protein expression and plasma RBP-4 levels (Graham et al., 2006; Esteve et al., 2009; Toruner et al., 2010). Decreased GLUT4 expression is accompanied by increased RBP-4 secretion in the adipose tissue of obese subjects and reduced GLUT4 expression can be caused by increased RBP-4 secretion (Yang et al., 2005). In liver, RBP-4 stimulates the expression of phosphoenolpyruvate carboxykinase (PEPCK) enzyme, a gluconeogenic enzyme that is stimulated by glucagon and inhibited by insulin (Quinn and Yeagley, 2005), leading to impaired insulin signaling in hepatocytes (Yang et al., 2005).

Most but not all of the findings suggest that plasma RBP-4 levels are positively associated with body fat percentage and insulin resistance (Janke et al., 2006; von Eynatten et al., 2007; Yao-Borengasser et al., 2007; Bajzova et al., 2008; Gomez-Ambrosi et al., 2008). Obese subjects have higher plasma RBP-4 levels than lean subjects. Plasma RBP-4 levels are positively correlated with insulin resistance in subjects with obesity, impaired glucose tolerance, or type 2 diabetes (Graham et al., 2006). RBP-4 levels were significantly decreased following weight loss after a bariatric surgery (Haider et al., 2007; Gomez-Ambrosi et al., 2008; Tschoner et al., 2008). Barazzoni et al. (2011) showed that high plasma RBP-4 levels was correlated with high systemic inflammatory responses in non-obese, non-diabetic patients with chronic kidney disease (But the correlation was independent of RBP-4 expression in adipose tissue. More studies are required to investigate the roles of RBP-4 in inflammation.

\section{OTHER CHANGES IN GASTROINTESTINAL SYSTEM AFTER BARIATRIC SURGERY}

After a meal, gastrointestinal system secretes incretins including glucose dependent insulinotropic polypeptide (GIP) and glucagon-like peptide 1 (GLP-1), which stimulate post-prandial insulin secretion (Holst, 2013; Holst and Deacon, 2013). GIP is secreted by duodenal $\mathrm{K}$ cells and GLP-1 is secreted by ileal L cells (Holst, 2013). These incretins have insulinotropic effects, furthermore; GLP-1 delays gastric emptying and decreases appetite leading to increased weight loss and insulin sensitivity (Flint et al., 2001; Laferrère, 2011). GLP-1 is increased after Roux-en-Y gastric bypass and biliopancreatic diversion (Näslund et al., 1997, 1998). Even though inconclusive findings on effects of the bariatric surgery on blood GIP levels are reported (Näslund et al., 1998; Laferrère, 2011, 2012), Laferrère et al. (2007) showed increased blood GIP levels 1 month and 1 year after Roux-en-Y surgery in patients with type 2 diabetes. Näslund et al. (1997) reported that the increase in blood GLP-1 and GIP levels is persistent for 20 years after duodenal jejunal bypass. More studies are required to investigate the effects of GLP-1 and GIP changes on inflammation in obese subjects following bariatric surgery.

There are two hypotheses trying to explain the increase in incretins secretion; foregut; and hindgut hypotheses (Strader et al., 2005; Strader, 2006; Pacheco et al., 2007; Hansen et al., 2011; de Luis et al., 2012). Foregut hypothesis suggests that bypassing duodenum and proximal jejunum increases incretin secretion which improves insulin sensitivity more than weight loss itself (Pacheco et al., 2007; Hansen et al., 2011; de Luis et al., 2012). However, research studies in Roux-en-Y gastric bypass and vertical sleeve gastrectomy which does not bypass duodenum or jejunum reported similar incretin secretion levels, therefore invalidating the foregut hypothesis (Chambers et al., 2011). Hindgut hypothesis suggests that instant stimulation of ileum by the nutrients causes the increase in blood GLP-1 levels (Strader et al., 2005; Strader, 2006). After Roux-en-Y gastric bypass, emptying of the stomach is fast and nutrients reach to ileum rapidly which might be the cause of increased GLP-1 secretion (Morínigo et al., 2006). 
Bariatric surgery alters gut microbiota dramatically (Zhang et al., 2009; Furet et al., 2010; Clément, 2011; Kootte et al., 2012; Sweeney and Morton, 2013). Zhang et al. (2009) showed a positive association between Archaea and obesity. They found no Archaea in normal weight subjects and a decreased number in subjects who underwent gastric bypass surgery. Furet et al. (2010) demonstrated a decrease in Prevotellacaea during obesity, but the number of Prevotellacaea was rapidly increased after gastric bypass surgery. Zhang et al. showed obese subjects had more Bacteroidetes than lean subjects. Contrary to Furet et al. findings, Prevotellacaea, which is a subgroup of Bacteroidetes, was enriched in obese subjects. Furthermore, Ley et al. (2006) found no difference in the amount of Bacteroidetes between lean and obese subjects. These inconclusive data indicate that weight loss might be affecting subgroups differently. Effects of gut microbiota changes after bariatric surgery on inflammation, insulin resistance, and diabetes are not completely understood (Kootte et al., 2012). However, even though there might be positive effect of gut microbiota change on insulin sensitivity, this effect probably is overridden by possible malnutrition state after bariatric surgeries (Kootte et al., 2012).

\section{CONCLUSION AND FUTURE DIRECTIONS}

Obesity is a chronic low-grade inflammatory disease. In adipose tissue, both adipocytes and macrophages secrete a large number of hormones, proteins, cytokines, and chemokines, collectively called adipokines. These adipokines contribute to the pathogenesis of metabolic syndrome, insulin resistance, type 2 diabetes, and cardiovascular disease, most likely via regulating the inflammatory pathway mediated by TNF- $\alpha$, IL-6, NF-kB, JNK, and IKK and insulin signaling pathway mediated by IRSs, PI3k/Akt, and SOCSs. Weight loss via surgeries dramatically alters levels of these adipokines and overall increases insulin sensitivity. However,

\section{REFERENCES}

Adya, R., Tan, B. K., Punn, A., Chen, J., and Randeva, H. S. (2008a). Visfatin induces human endothelial VEGF and MMP-2/9 production via MAPK and PI3K/Akt signalling pathways: novel insights into visfatin-induced angiogenesis. Cardiovasc. Res. 78, 356-365. doi:10.1093/cvr/cvm111

Adya, R., Tan, B. K., Chen, J., and Randeva, H. S. (2008b). Nuclear factor-kappaB induction by visfatin in human vascular endothelial cells: its role in MMP-2/9 production and activation. Diabetes Care 31,758-760. doi:10.2337/dc071544

Alghasham, A. A., and Barakat, Y. A. (2008). Serum visfatin and its relation to insulin resistance and inflammation in type 2 diabetic patients with and without macroangiopathy. Saudi Med. J. 29, 185-192.

Amati, L., Marzulli, G., Martulli, M., Chiloiro, M., and Jirillo, E.

despite ample evidence supporting the role of these adipokines in obesity and insulin resistance, mechanisms mediating their effects are for the most part still unclear. It is also unclear whether or how these adipokines mediate the effect of weight loss surgeries such as bariatric surgery on inflammation and insulin response. Further studies are required to better understand the relationship between those adipokines and insulin resistance and how these are modulated by bariatric surgery. Alteration in the adipokine profile primarily reflects changes in adipose-tissue production and secretion of these cytokines. Thus, additional studies are needed to determine whether reduced adipose-tissue inflammation following bariatric surgery is responsible for reduced systemic inflammation and improved insulin sensitivity. Furthermore, the development of animal models which recapitulate the bariatric surgery model will lead to a better understanding of mechanisms by which this surgery improves metabolic outcomes related to diabetes and obesity. It is especially important to understand whether the beneficial effects of bariatric surgery are solely related to weight loss, improved adipose-tissue inflammation and/or changes in gut physiology and endocrinology. In addition, with an adequately powered sample sizes for cross-sectional or case-control studies, the various types of adipose tissues, including subcutaneous, omental, and mesenteric adipose tissues, along with plasma and other tissues, can be collected from severely obese patients who undergo bariatric surgery. Finally, long term studies are critical to assess whether weight loss surgery and associated metabolic improvements are sustained over a long period of time and whether these are primarily related to weight loss or other beneficial effects of the bariatric surgery.

\section{ACKNOWLEDGMENTS}

The work was supported by the College of Human Sciences at Texas Tech University.

stimulates glucose uptake but not lipolysis in human adipose tissue ex vivo. J. Mol. Endocrinol. 46, 21-28. doi:10.1677/JME-10-0105

Bajzova, M., Kovacikova, M., Vitkova, M., Klimcakova, E., Polak, J., Kovacova, Z., et al. (2008). Retinolbinding protein 4 expression in visceral and subcutaneous fat in human obesity. Physiol. Res. 57, 927-934.

Balistreri, C. R., Caruso, C., and Candore, G. (2010). The role of adipose tissue and adipokines in obesity-related inflammatory diseases. Mediators Inflamm. 2010, 802078. doi:10.1155/2010/802078

Barazzoni, R., Zanetti, M., Semolic, A., Pirulli, A., Cattin, M. R., Biolo, G., et al. (2011). High plasma RBP4 is associated with systemic inflammation independently of low RBP4 adipose expression and is normalized by transplantation in non-obese, non-diabetic patients with chronic kidney disease. Clin.
Endocrinol. doi:10.1111/j.13652265.2011.03990.x. [Epub ahead of print].

Bell, L. N., Ward, J. L., DegawaYamauchi, M., Bobenkerk, J. E., Jones, R., Cacucci, B. M., et al. (2006). Adipose tissue production of hepatocyte growth factor contributes to elevated serum HGF in obesity. Am. J. Physiol. Endocrinol. Metab. 291, E843-E848. doi:10.1152/ajpendo. 00174.2006

Beltowski, J. (2006). Apelin and visfatin: unique "beneficial" adipokines upregulated in obesity? Med. Sci. Monit. 12, RA112-RA119.

Bhattacharya, J., and Sood, N. (2011). Who pays for obesity? J. Econ. Perspect. 25, 139-158. doi:10.1257/jep.25.1.139

Bluher, M. (2012). Vaspin in obesity and diabetes: pathophysiological and clinical significance. Endocrine 41, 176-182. doi:10.1007/s12020011-9572-0 
Blüher, M., Fasshauer, M., Tönjes, A., Kratzsch, J., Schön, M. R., and Paschke, R. (2005). Association of interleukin-6, Creactive protein, interleukin-10 and adiponectin plasma concentrations with measures of obesity, insulin sensitivity and glucose metabolism. Exp. Clin. Endocrinol. Diabetes 113, 534-537. doi:10.1055/ s-2005-872851

Boesing, F., Moreira, E. A., WilhelmFilho, D., Vigil, S. V., Parizottto, E. B., Inacio, D. B., et al. (2010). Rouxen-Y bypass gastroplasty: markers of oxidative stress 6 months after surgery. Obes. Surg. 20, 1236-1244. doi:10.1007/s11695-010-0196-x

Botella-Carretero, J. I., Luque-Ramirez, M., Alvarez-Blasco, F., Peromingo, R., San Millan, J. L., and EscobarMorreale, H. F. (2008). The increase in serum visfatin after bariatric surgery in morbidly obese women is modulated by weight loss, waist circumference, and presence or absence of diabetes before surgery. Obes. Surg. 18, 1000-1006. doi:10.1007/s11695-007-9369-7

Boucher, J., Masri, B., Daviaud, D., Gesta, S., Guigne, C., Mazzucotelli, A., et al. (2005). Apelin, a newly identified adipokine upregulated by insulin and obesity. Endocrinology 146, 1764-1771. doi:10.1210/en.2004-1427

Butner, K. L., Nickols-Richardson, S. M., Clark, S. F., Ramp, W. K., and Herbert, W. G. (2010). A review of weight loss following Roux-en-Y gastric bypass vs restrictive bariatric surgery: impact on adiponectin and insulin. Obes. Surg. 20, 559-568. doi:10.1007/s11695-010-0089-z

Cai, D., Dhe-Paganon, S., Melendez, P. A., Lee, J., and Shoelson, S. E. (2003). Two new substrates in insulin signaling, IRS5/DOK4 and IRS6/DOK5. J. Biol. Chem. 278, 25323-25330. doi:10.1074/jbc.M212430200

Camerini, G., Adami, G., Marinari, G. M., Gianetta, E., Pretolesi, F., Papadia, F., et al. (2004). Thirteen years of follow-up in patients with adjustable silicone gastric banding for obesity: weight loss and constant rate of late specific complications. Obes. Surg. 14, 1343-1348. doi:10.1381/0960892042584049

Cancello, R., Henegar, C., Viguerie, N., Taleb, S., Poitou, C., Rouault, C., et al. (2005). Reduction of macrophage infiltration and chemoattractant gene expression changes in white adipose tissue of morbidly obese subjects after surgery-induced weight loss. Diabetes 54, 2277-2286. doi:10.2337/diabetes.54.8.2277
Castan-Laurell, I., Dray, C., Attane, C., Duparc, T., Knauf, C., and Valet, P. (2011). Apelin, diabetes, and obesity. Endocrine 40, 1-9. doi:10.1007/s12020-011-9507-9

Catalan, V., Gomez-Ambrosi, J., Ramirez, B., Rotellar, F., Pastor, C., Silva, C., et al. (2007). Proinflammatory cytokines in obesity: impact of type 2 diabetes mellitus and gastric bypass. Obes. Surg. 17, 1464-1474. doi:10.1007/s11695-008-9424-z

Catalan, V., Gomez-Ambrosi, J., Rodriguez, A., Ramirez, B., Silva, C., Rotellar, F., et al. (2009). Increased adipose tissue expression of lipocalin-2 in obesity is related to inflammation and matrix metalloproteinase2 and metalloproteinase-9 activities in humans. J. Mol. Med. (Berl.) 87, 803-813. doi:10.1007/s00109-009-0486-8

Cesari, M., Kritchevsky, S. B., Baumgartner, R. N., Atkinson, H. H., Penninx, B. W., Lenchik, L., et al. (2005). Sarcopenia, obesity, and inflammationresults from the Trial of Angiotensin Converting Enzyme Inhibition and Novel Cardiovascular Risk Factors study. Am. J. Clin. Nutr. 82, 428-434. Chambers, A. P., Stefater, M. A., WilsonPerez, H. E., Jessen, L., Sisley, S., Ryan, K. K., et al. (2011). Similar effects of roux-en-Y gastric bypass and vertical sleeve gastrectomy on glucose regulation in rats. Physiol. Behav. 105, 120-123. doi:10.1016/j.physbeh.2011.05.026

Chang, H. M., Lee, H. J., Park, H. S., Kang, J. H., Kim, K. S., Song, Y. S., et al. (2010). Effects of weight reduction on serum vaspin concentrations in obese subjects: modification by insulin resistance. Obesity (Silver Spring) 18, 2105-2110. doi:10.1038/oby.2010.60

Charles, B. A., Doumatey, A., Huang, H., Zhou, J., Chen, G., Shriner, D., et al. (2011). The roles of IL-6, IL-10, and IL-1RA in obesity and insulin resistance in African-Americans. J. Clin. Endocrinol. Metab. 96, E2018-2022. doi:10.1210/jc.2011-1497

Clément, K. (2011). Bariatric surgery, adipose tissue and gut microbiota. Int. J. Obes. (Lond.) 35(Suppl. 3), S7-15. doi:10.1038/ijo.2011.141

Compher, C., and Badellino, $\mathrm{K}$. O. (2008). Obesity and inflammation: lessons from bariatric surgery. JPEN J. Parenter. Enteral. Nutr. 32, 645-647. doi:10.1177/0148607108326070

Coppack, S. W. (2001). Proinflammatory cytokines and adipose tissue. Proc. Nutr. Soc. 60, 349-356. doi:10.1079/PNS2001110
Daviaud, D., Boucher, J., Gesta, S. Dray, C., Guigne, C., Quilliot, D., et al. (2006). TNFalpha up-regulates apelin expression in human and mouse adipose tissue. FASEB J. 20, 1528-1530. doi:10.1096/fj.055243fje

de Luis, D., Domingo, M., Romero, A., Gonzalez Sagrado, M., Pacheco, D., Primo, D., et al. (2012) Effects of duodenal-jejunal exclusion on beta cell function and hormonal regulation in Goto-Kakizaki rats. Am. J. Surg. 204, 242-247. doi:10.1016/j.amjsurg.2011.07.020

De Luis, D. A., Gonzalez Sagrado, M., Conde, R., Aller, R., and Izaola, O. (2010). Resistin levels and inflammatory markers in patients with morbid obesity. Nutr. Hosp. 25, 630-634.

Dhanasekaran, D. N., and Johnson, G. L. (2007). MAPKs: function, regulation, role in cancer and therapeutic targeting. Oncogene 26, 3097-3099. doi:10.1038/sj.onc.1210395

Dogru, T., Sonmez, A., Tasci, I. Bozoglu, E., Yilmaz, M. I., Genc, H., et al. (2007). Plasma visfatin levels in patients with newly diagnosed and untreated type 2 diabetes mellitus and impaired glucose tolerance. Diabetes Res. Clin. Pract. 76, 24-29. doi:10.1016/ j.diabres.2006.07.031

Dray, C., Debard, C., Jager, J., Disse, E., Daviaud, D., Martin, P., et al. (2010). Apelin and APJ regulation in adipose tissue and skeletal muscle of type 2 diabetic mice and humans. Am. J. Physiol. Endocrinol. Metab. 298,E1161-1169. doi:10.1152/ajpendo.00598.2009

Dray, C., Knauf, C., Daviaud, D. Waget, A., Boucher, J., Buleon, M., et al. (2008). Apelin stimulates glucose utilization in normal and obese insulin-resistant mice. Cell Metab. 8, 437-445. doi:10.1016/j.cmet.2008.10.003

Edwards, C., Hindle, A. K., Fu, S. and Brody, F. (2010). Downregulation of leptin and resistin expression in blood following bariatric surgery. Surg. Endosc. 25, 1962-1968. doi:10.1007/s00464-010-1494-z

Eisenhardt, S. U., Thiele, J. R., Bannasch, H., Stark, G. B., and Peter, K. (2009). C-reactive protein: how conformational changes influence inflammatory properties. Cell Cycle 8, 3885-3892. doi:10.4161/cc.8.23.10068

El-Mesallamy, H. O., Kassem, D. H., El-Demerdash, E., and Amin, A. I. (2011). Vaspin and visfatin/Nampt are interesting interrelated adipokines playing a role in the pathogenesis of type 2 diabetes mellitus. Metab. Clin. Exp. 60, 63-70. doi:10.1016/j.metabol.2010. 04.008

Esteve, E., Ricart, W., and FernandezReal, J. M. (2009). Adipocytokines and insulin resistance: the possible role of lipocalin-2, retinol binding protein-4, and adiponectin. Diabetes Care 32(Suppl. 2), S362-S367. doi:10.2337/dc09-S340

Fain, J. N. (2010). Release of inflammatory mediators by human adipose tissue is enhanced in obesity and primarily by the nonfat cells: a review. Mediators Inflamm. 2010, 513948. doi:10.1155/2010/513948

Fantuzzi, G. (2008). Adiponectin and inflammation: consensus and controversy. J. Allergy Clin. Immunol. 121, 326-330. doi:10.1016/j.jaci.2007.10.018

Fernandez-Veledo, S., Nieto-Vazquez, I., Vila-Bedmar, R., Garcia-Guerra, L., Alonso-Chamorro, M., and Lorenzo, M. (2009). Molecular mechanisms involved in obesityassociated insulin resistance: therapeutical approach. Arch. Physiol. Biochem. 115, 227-239. doi:10.1080/13813450903164330

Filkova, M., Haluzik, M., Gay, S., and Senolt, L. (2009). The role of resistin as a regulator of inflammation: implications for various human pathologies. Clin. Immunol. 133, 157-170. doi:10.1016/j.clim.2009.07.013

Flint, A., Raben, A., Ersbøll, A. K., Holst, J. J., and Astrup, A. (2001). The effect of physiological levels of glucagon-like peptide-1 on appetite, gastric emptying, energy and substrate metabolism in obesity. Int. J. Obes. Relat. Metab. Disord. 25, 781-792. doi:10.1038/sj.ijo.0801627

Franco, J. V. A., Ruiz, P. A., Palermo, M., and Gagner, M. (2011). A review of studies comparing three laparoscopic procedures in bariatric surgery: sleeve gastrectomy, Roux-en-Y gastric bypass and adjustable gastric banding. Obes. Surg. 21, 1458-1468. doi:10.1007/s11695-011-0390-5

Friebe, D., Neef, M., Kratzsch, J., Erbs, S., Dittrich, K., Garten, A., et al. (2011). Leucocytes are a major source of circulating nicotinamide phosphoribosyltransferase (NAMPT)/pre-B cell colony (PBEF)/visfatin linking obesity and inflammation in humans. Diabetologia 54, 1200-1211. doi:10.1007/s00125-010-2042-z

Fukuhara, A., Matsuda, M., Nishizawa, M., Segawa, K., Tanaka, M., Kishimoto, K., et al. (2005). Visfatin: 
a protein secreted by visceral fat that mimics the effects of insulin. Science 307, 426-430. doi:10.1126/science.1097243

Furet, J. P., Kong, L. C., Tap, J., Poitou, C., Basdevant, A., Bouillot, J. L., et al. (2010). Differential adaptation of human gut microbiota to bariatric surgeryinduced weight loss: links with metabolic and low-grade inflammation markers. Diabetes 59, 3049-3057. doi:10.2337/db10-0253

García de la Torre, N., Rubio, M. A., Bordiú, E., Cabrerizo, L., Aparicio, E., Hernández, C., et al. (2008). Effects of weight loss after bariatric surgery for morbid obesity on vascular endothelial growth factor-A, adipocytokines, and insulin. J. Clin. Endocrinol. Metab. 93, 4276-4281. doi:10.1210/jc.2007-1370

Garcia-Fuentes, E., Garcia-Almeida, J. M., Garcia-Arnes, J., GarciaSerrano, S., Rivas-Marin, J., Gallego-Perales, J. L., et al. (2007). Plasma visfatin concentrations in severely obese subjects are increased after intestinal bypass. Obesity (Silver Spring) 15, 2391-2395. doi:10.1038/oby.2007.284

Gomez-Ambrosi, J., Rodriguez, A., Catalan, V., Ramirez, B., Silva, C., Rotellar, F., et al. (2008). Serum retinol-binding protein 4 is not increased in obesity or obesityassociated type 2 diabetes mellitus, but is reduced after relevant reductions in body fat following gastric bypass. Clin. Endocrinol. (Oxf.) 69, 208-215. doi:10.1111/j.13652265.2007.03156.x

Gomez-Illan, F., Gonzalvez-Ortega, M., Orea-Soler, I., Alcaraz-Tafalla, S., Aragon-Alonso, A., Pascual-Diaz, M., et al. (2012). Obesity and inflammation: change in adiponectin, $\mathrm{C}$ reactive protein, tumor necrosis factor-alpha and Interleukin-6 after bariatric surgery. Obesity Surgery 22, 950-955. doi:10.1007/s11695012-0643-y

Graham, T. E., Yang, Q., Bluher, M., Hammarstedt, A., Ciaraldi, T. P., Henry, R. R., et al. (2006). Retinol-binding protein 4 and insulin resistance in lean, obese, and diabetic subjects. $N$. Engl. J. Med. 354, 2552-2563. doi:10.1056/NEJMoa054862

Haider, D. G., Schindler, K., Prager, G., Bohdjalian, A., Luger, A., Wolzt, M., et al. (2007). Serum retinolbinding protein 4 is reduced after weight loss in morbidly obese subjects. J. Clin. Endocrinol. Metab. 92, 1168-1171. doi:10.1210/jc.20061839
Hajer, G. R., van Haeften, T. W., and Visseren, F. L. (2008). Adipose tissue dysfunction in obesity, diabetes, and vascular diseases. Eur. Heart J. 29, 2959-2971. doi:10.1093/eurheartj/ehn387

Handisurya, A., Riedl, M., Vila, G., Maier, C., Clodi, M., Prikoszovich, T., et al. (2010). Serum vaspin concentrations in relation to insulin sensitivity following RYGB-induced weight loss. Obes. Surg. 20, 198-203. doi:10.1007/s11695-009-9882-y

Hansen, E. N., Tamboli, R. A., Isbell, J. M., Saliba, J., Dunn, J. P., Marks-Shulman, P. A., et al. (2011). Role of the foregut in the early improvement in glucose tolerance and insulin sensitivity following Roux-en-Y gastric bypass surgery. Am. J. Physiol. Gastrointest. Liver Physiol. 300, G795-G802. doi:10.1152/ajpgi.00019.2011

Heinonen, M. V., Purhonen, A. K., Miettinen, P., Pääkkönen, M., Pirinen, E., Alhava, E., et al. (2005). Apelin, orexin-A and leptin plasma levels in morbid obesity and effect of gastric banding. Regul. Pept. 130, 7-13. doi:10.1016/j.regpep.2005.05.003

Hell, E., and Miller, K. (2002). Criteria for selection of patients for bariatric surgery. Zentralbl. Chir. 127, 1035-1037. doi:10.1055/s2002-36375

Herder, C., Schneitler, S., Rathmann, W., Haastert, B., Schneitler, H., Winkler, H., et al. (2007). Low-grade inflammation, obesity, and insulin resistance in adolescents. J. Clin. Endocrinol. Metab. 92, 4569-4574. doi:10.1210/jc.2007-0955

Hida, K., Wada, L., Eguchi, J., Zhang, H., Baba, M., Seida, A., et al. (2005). Visceral adipose tissuederived serine protease inhibitor: a unique insulin-sensitizing adipocytokine in obesity. Proc. Natl. Acad. Sci. U.S.A. 102, 10610-10615. doi:10.1073/pnas.0504703102

Hofso, D., Nordstrand, N., Johnson, L. K., Karlsen, T. I., Hager, H., Jenssen, T., et al. (2010). Obesity-related cardiovascular risk factors after weight loss: a clinical trial comparing gastric bypass surgery and intensive lifestyle intervention. Eur. J. Endocrinol. 163, 735-745. doi:10.1530/EJE-10-0514

Holdstock, C., Lind, L., Engstrom, B. E., Ohrvall, M., Sundbom, M., Larsson, A., et al. (2005). CRP reduction following gastric bypass surgery is most pronounced in insulin-sensitive subjects. Int. J. Obes. (Lond.) 29, 1275-1280. doi:10.1038/sj.ijo.0803000

Holst, J. J. (2013). Incretin hormones and the satiation signal. Int. J. Obes.
(Lond.) doi:10.1038/ijo.2012.208 [Epub ahead of print].

Holst, J. J., and Deacon, C. F. (2013). Is there a place for incretin therapies in obesity and prediabetes? Trends Endocrinol. Metab. 24, 145-152. doi:10.1016/j.tem.2013.01.004

Iannelli, A., Anty, R., Piche, T., Dahman, M., Gual, P., Tran, A., et al. (2009). Impact of laparoscopic Roux-en-Y gastric bypass on metabolic syndrome, inflammation, and insulin resistance in super versus morbidly obese women. Obes. Surg. 19, 577-582. doi:10.1007/s11695008-9764-8

Iannelli, A., Anty, R., Schneck, A. S., Tran, A., and Gugenheim, J. (2010). Inflammation, insulin resistance, lipid disturbances, anthropometrics, and metabolic syndrome in morbidly obese patients: a case control study comparing laparoscopic Roux-en-Y gastric bypass and laparoscopic sleeve gastrectomy. Surgery 149, 364-370. doi:10. 1016/j.surg.2010.08.013

Iqbal, N., Seshadri, P., Stern, L., Loh, J., Kundu, S., Jafar, T., et al. (2005). Serum resistin is not associated with obesity or insulin resistance in humans. Eur. Rev. Med. Pharmacol. Sci. 9, 161-165.

Israel, A. (2010). The IKK complex, a central regulator of NFkappaB activation. Cold Spring Harb. Perspect. Biol. 2, a000158. doi:10.1101/cshperspect.a000158

Jagannathan, M., McDonnell, M., Liang, Y., Hasturk, H., Hetzel, J., Rubin, D., et al. (2010). Toll-like receptors regulate B cell cytokine production in patients with diabetes. Diabetologia 53, 1461-1471. doi:10.1007/s00125010-1730-z

Janke, J., Engeli, S., Boschmann, M., Adams, F., Bohnke, J., Luft, F. C., et al. (2006). Retinol-binding protein 4 in human obesity. Diabetes 55 , 2805-2810. doi:10.2337/db06-0616

Jankiewicz-Wika, J., Kolomecki, K., Cywinski, J., Piestrzeniewicz, K., Swietoslawski, J., Stepien, H., et al. (2011). Impact of vertical banded gastroplasty on body weight, insulin resistance, adipocytokine, inflammation and metabolic syndrome markers in morbidly obese patients. Endokrynol. Pol. 62, 109-119.

Jaunoo, S. S., and Southall, P. J. (2010). Bariatric surgery. Int. J. Surg. 8, 86-89. doi:10.1016/j.ijsu.2009.12.003

Joao Cabrera, E., Valezi, A. C., Delfino, V. D., Lavado, E. L., and Barbosa, D. S. (2010). Reduction in plasma levels of inflammatory and oxidative stress indicators after Roux-en-Y gastric bypass. Obes. Surg. 20, 42-49. doi:10.1007/s11695-009-9988-2

Johnston, J. A., and O'Shea, J. J. (2003). Matching SOCS with function. Nat. Immunol. 4, 507-509. doi:10.1038/ni0603-507

Kadoglou, N. P., Tsanikidis, H., Kapelouzou, A., Vrabas, I., Vitta, I., Karayannacos, P. E., et al. (2010). Effects of rosiglitazone and metformin treatment on apelin, visfatin, and ghrelin levels in patients with type 2 diabetes mellitus. Metab. Clin. Exp. 59, 373-379. doi:10.1016/j.metabol.2009.08.005

Kalupahana, N. S., Claycombe, K. J., and Moustaid-Moussa, N. (2011). (n-3) Fatty acids alleviate adipose tissue inflammation and insulin resistance: mechanistic insights. Adv. Nutr. 2, 304-316. doi:10.3945/an.111.000505

Kalupahana, N. S., Moustaid-Moussa, N., and Claycombe, K. J. (2012). Immunity as a link between obesity and insulin resistance. Mol. Aspects Med. 33, 26-34. doi:10.1016/j.mam.2011.10.011

Kanda, H., Tateya, S., Tamori, Y., Kotani, K., Hiasa, K., Kitazawa, R., et al. (2006). MCP-1 contributes to macrophage infiltration into adipose tissue, insulin resistance, and hepatic steatosis in obesity. J. Clin. Invest. 116, 1494-1505. doi:10.1172/JCI26498

Kempf, K., Rose, B., Illig, T., Rathmann, W., Strassburger, K., Thorand, B., et al. (2010). Vaspin (SERPINA12) genotypes and risk of type 2 diabetes: results from the MONICA/KORA studies. Exp. Clin. Endocrinol. Diabetes 118, 184-189. doi:10.1055/s-2008-1081499

Kim, S. R., Bae, S. K., Choi, K. S., Park, S. Y., Jun, H. O., Lee, J. Y., et al. (2007). Visfatin promotes angiogenesis by activation of extracellular signal-regulated kinase 1/2. Biochem. Biophys. Res. Commun. 357, 150-156. doi:10.1016/j.bbrc.2007.03.105

Kim, S. R., Bae, Y. H., Bae, S. K., Choi, K. S., Yoon, K. H., Koo, T. H., et al. (2008). Visfatin enhances ICAM-1 and VCAM-1 expression through ROS-dependent NF-kappaB activation in endothelial cells. Biochim. Biophys. Acta 1783, 886-895. doi:10.1016/j.bbamcr.2008.01.004

Kloting, N., Berndt, J., Kralisch, S., Kovacs, P., Fasshauer, M., Schon, M. R., et al. (2006). Vaspin gene expression in human adipose tissue: association with obesity and type 2 diabetes. Biochem. Biophys. Res. Commun. 339, 430-436. doi:10.1016/j.bbrc.2005.11.039 
Kones, R. (2010). Rosuvastatin, inflammation, C-reactive protein, JUPITER, and primary prevention of cardiovascular disease - a perspective. Drug Des. Devel. Ther. 4, 383-413. doi:10.2147/DDDT.S10812

Kootte, R. S., Vrieze, A., Holleman, F., Dallinga-Thie, G. M., Zoetendal, E. G., de Vos, W. M., et al. (2012). The therapeutic potential of manipulating gut microbiota in obesity and type 2 diabetes mellitus. Diabetes Obes. Metab. 14, 112-120. doi:10.1111/j.14631326.2011.01483.x

Krist, J., Wieder, K., Klöting, N., Oberbach, A., Kralisch, S., Wiesner, T., et al. (2013). Effects of weight loss and exercise on apelin serum concentrations and adipose tissue expression in human obesity. Obes. Facts 6 , 57-69. doi:10.1159/000348667

Krzyzanowska, K., Mittermayer, F., Krugluger, W., Kopp, H. P., and Schernthaner, G. (2006). Increase in visfatin after weight loss induced by gastroplastic surgery. Obesity (Silver Spring) 14, 1886-1889. doi:10.1038/oby.2006.219

Kukla, M., Mazur, W., Buldak, R. J., and Zwirska-Korczala, K. (2011). Potential role of leptin, adiponectin and the novel adipokines-visfatin, chemerin and vaspin-in chronic hepatitis. Mol. Med. 17, 1397-1410. doi:10.2119/molmed.2010.00105

Kulick, D., Hark, L., and Deen, D. (2010). The bariatric surgery patient: a growing role for registered dietitians. J. Am. Diet. Assoc. 110, 593-599. doi:10.1016/j.jada.2009.12.021

Laferrère, B. (2011). Do we really know why diabetes remits after gastric bypass surgery? Endocrine 40, 162-167. doi:10.1007/s12020011-9514-X

Laferrère, B. (2012). Gut feelings about diabetes. Endocrinol. Nutr. 59, 254-260. doi:10.1016/j.endonu.2012.01.010

Laferrère, B., Heshka, S., Wang, K., Khan, Y., McGinty, J., Teixeira, J., et al. (2007). Incretin levels and effect are markedly enhanced 1 month after Roux-en-Y gastric bypass surgery in obese patients with type 2 diabetes. Diabetes Care 30, 1709-1716. doi:10.2337/dc061549

Lee, D. K., George, S. R., and O'Dowd, B. F. (2006). Unravelling the roles of the apelin system: prospective therapeutic applications in heart failure and obesity. Trends Pharmacol. Sci. 27, 190-194. doi:10.1016/j.tips.2006.02.006
Lee, J. A., Park, H. S., Song, Y. S., Jang, Y. J., Kim, J. H., Lee, Y. J., et al. (2011). Relationship between vaspin gene expression and abdominal fat distribution of Korean women. Endocr. J. 58, 639-646. doi:10.1507/endocrj.K11E-073

Lee, J. H., Chan, J. L., Yiannakouris, N., Kontogianni, M., Estrada, E., Seip, R., et al. (2003). Circulating resistin levels are not associated with obesity or insulin resistance in humans and are not regulated by fasting or leptin administration: cross-sectional and interventional studies in normal, insulin-resistant, and diabetic subjects. J. Clin. Endocrinol. Metab. 88, 4848-4856. doi:10.1210/jc.2003030519

Leff, T., Mathews, S. T., and Camp, H. S. (2004). Review: peroxisome proliferator-activated receptor-gamma and its role in the development and treatment of diabetes. Exp. Diabesity Res. 5, 99-109. doi:10.1080/15438600490451668

Leick, L., Lindegaard, B., Stensvold, D., Plomgaard, P., Saltin, B., and Pilegaard, H. (2007). Adipose tissue interleukin-18 mRNA and plasma interleukin-18: effect of obesity and exercise. Obesity 15, 356-363. doi:10.1038/oby.2007.528

Ley, R. E., Turnbaugh, P. J., Klein, S., and Gordon, J. I. (2006). Microbial ecology: human gut microbes associated with obesity. Nature 444, 1022-1023. doi:10.1038/4441022a

Li, Q., Chen, R., Moriya, J., Yamakawa, J., Sumino, H., Kanda, T., et al. (2008). A novel adipocytokine, visceral adipose tissue-derived serine protease inhibitor (vaspin), and obesity. J. Int. Med. Res. 36, 625-629. doi:10.1177/147323000803600402

Li, K., Li, L., Yang, M., Liu, H., Liu, D., Yang, H., et al. (2011). Short-term continuous subcutaneous insulin infusion decreases the plasma vaspin levels in patients with type 2 diabetes mellitus concomitant with improvement in insulin sensitivity. Eur. J. Endocrinol. 164, 905-910. doi:10.1530/EJE-10-1023

Liu, S., Tinker, L., Song, Y., Rifai, N., Bonds, D. E., Cook, N. R., et al. (2007). A prospective study of inflammatory cytokines and diabetes mellitus in a multiethnic cohort of postmenopausal women. Arch. Intern. Med. 167, 1676-1685. doi:10.1001/archinte.167.15.1676

Maenhaut, N., and Van de Voorde, J. (2011). Regulation of vascular tone by adipocytes. BMC Med. 9:25. doi:10.1186/1741-7015-9-25

Malavazos, A. E., Cereda, E., Morricone, L., Coman, C., Corsi, M. M., and Ambrosi, B. (2005). Monocyte chemoattractant protein 1: possible link between visceral adipose tissue-associated inflammation and subclinical echocardiographic abnormalities in uncomplicated obesity. Eur. J. Endocrinol. 153, 871-877. doi:10.1530/eje.1.02033

Marantos, G., Daskalakis, M., Karkavitsas, N., Matalliotakis, I., Papadakis, J. A., and Melissas, J. (2011). Changes in metabolic profile and adipoinsular axis in morbidly obese premenopausal females treated with restrictive bariatric surgery. World J. Surg. 35, 2022-2030. doi:10.1007/s00268-011-1165-9

Mattar, S. G., Velcu, L. M., Rabinovitz, M., Demetris, A. J., Krasinskas, A. M., Barinas-Mitchell, E., et al. (2005). Surgically-induced weight loss significantly improves nonalcoholic fatty liver disease and the metabolic syndrome. Ann. Surg. 242, 610-617. discussion 618-620,

McGee, K. C., Harte, A. L., da Silva, N. F., Al-Daghri, N., Creely, S. J., Kusminski, C. M., et al. (2011). Visfatin is regulated by rosiglitazone in type 2 diabetes mellitus and influenced by NFkappaB and JNK in human abdominal subcutaneous adipocytes. PLoS ONE 6:e20287. doi:10.1371/journal.pone.0020287

Memoli, B., Procino, A., Calabro, P., Esposito, P., Grandaliano, G., Pertosa, G., et al. (2007). Inflammation may modulate IL-6 and C-reactive protein gene expression in the adipose tissue: the role of IL- 6 cell membrane receptor. Am. J. Physiol. Endocrinol. Metab. 293,E1030-1035. doi:10.1152/ajpendo.00697.2006

Monteiro, R., and Azevedo, I. (2010). Chronic inflammation in obesity and the metabolic syndrome. Mediators Inflamm. 2010:289645. doi:10.1155/2010/289645

Morínigo, R., Moizé, V., Musri, M. Lacy, A. M., Navarro, S., Marín, J. L., et al. (2006). Glucagon-like peptide-1, peptide YY, hunger, and satiety after gastric bypass surgery in morbidly obese subjects. J. Clin. Endocrinol. Metab. 91, 1735-1740. doi:10.1210/jc.2005-0904

Moschen, A. R., Molnar, C., Wolf, A. M., Weiss, H., Graziadei, I., Kaser, S., et al. (2009). Effects of weight loss induced by bariatric surgery on hepatic adipocytokine expression. J. Hepatol. 51, 765-777. doi:10.1016/j.jhep.2009.06.016

Mosser, D. M., and Edwards, J. P. (2008). Exploring the full spectrum of macrophage activation. Nat. Rev. Immunol. 8, 958-969. doi:10.1038/nri2448
Murri, M., Garcia-Fuentes, E., GarciaAlmeida, J. M., Garrido-Sanchez, L., Mayas, M. D., Bernal, R., et al. (2010). Changes in oxidative stress and insulin resistance in morbidly obese patients after bariatric surgery. Obes. Surg. 20, 363-368. doi:10.1007/s11695-009-0021-6

Mushtaq, M. U., Gull, S., Abdullah, H. M., Shahid, U., Shad, M. A., and Akram, J. (2011). Prevalence and socioeconomic correlates of overweight and obesity among Pakistani primary school children. BMC Public Health 11:724. doi:10.1186/14712458-11-724

Nash, A., Secker, D., Corey, M., Dunn, M., and O'Connor, D. L. (2008). Field testing of the 2006 World Health Organization growth charts from birth to 2 years: assessment of hospital undernutrition and overnutrition rates and the usefulness of BMI. JPEN J. Parenter. Enteral. Nutr. 32, 145-153. doi:10.1177/0148607108314386

Näslund, E., Backman, L., Holst, J. J., Theodorsson, E., and Hellström, P. M. (1998). Importance of small bowel peptides for the improved glucose metabolism 20 years after jejunoileal bypass for obesity. Obes. Surg. 8, 253-260. doi:10.1381/096089298765554449

Näslund, E., Grybäck, P., Hellström, P. M., Jacobsson, H., Holst, J. J., Theodorsson, E., et al. (1997). Gastrointestinal hormones and gastric emptying 20 years after jejunoileal bypass for massive obesity. Int. J. Obes. Relat. Metab. Disord. 21, 387-392. doi:10.1038/sj.ijo.0800418

Ndisang, J. F. (2010). Role of heme oxygenase in inflammation, insulinsignalling, diabetes and obesity. Mediators Inflamm. 2010, 359732. doi:10.1155/2010/359732

Nieto-Vazquez, I., Fernandez-Veledo, S., Kramer, D. K., Vila-Bedmar, R., Garcia-Guerra, L., and Lorenzo, M. (2008). Insulin resistance associated to obesity: the link TNF-alpha. Arch. Physiol. Biochem. 114, 183-194. doi:10.1080/13813450802181047

O’Rourke, R. W. (2009). Inflammation in obesity-related diseases. Surgery 145, 255-259. doi:10.1016/j.surg.2008.08.038

Oswal, A., and Yeo, G. (2010). Leptin and the control of body weight: a review of its diverse central targets, signaling mechanisms, and role in the pathogenesis of obesity. Obesity 18, 221-229. doi:10.1038/oby.2009.228

Pacheco, D., de Luis, D. A., Romero, A., González Sagrado, M., Conde, R., Izaola, O., et al. (2007). The 
effects of duodenal-jejunal exclusion on hormonal regulation of glucose metabolism in Goto-Kakizaki rats. Am. J. Surg. 194, 221-224. doi:10.1016/j.amjsurg.2006.11.015

Palin, M. F., Labrecque, B., Beaudry, D., Mayhue, M., Bordignon, V., and Murphy, B. D. (2008). Visfatin expression is not associated with adipose tissue abundance in the porcine model. Domest. Anim. Endocrinol. 35, 58-73. doi:10.1016/j.domaniend

Panee, J. (2012). Monocyte Chemoattractant Protein 1 (MCP-1) in obesity and diabetes. Cytokine 60, 1-12. doi:10.1016/j.cyto.2012.06.018

Park, E. J., Lee, J. H., Yu, G. Y., He, G., Ali, S. R., Holzer, R. G., et al. (2010). Dietary and genetic obesity promote liver inflammation and tumorigenesis by enhancing IL- 6 and TNF expression. [a]. Cell 140, 197-208. doi:10.1016/j.cell.2009.12.052

Park, H. S., Park, J. Y., and Yu, R. (2005). Relationship of obesity and visceral adiposity with serum concentrations of CRP, TNF-alpha and IL-6. Diabetes Res. Clin. Pract. 69, 29-35. doi:10.1016/j.diabres.2004.11.007

Pfutzner, A., and Forst, T. (2006). High-sensitivity C-reactive protein as cardiovascular risk marker in patients with diabetes mellitus. Diabetes Technol. Ther. 8, 28-36. doi:10.1089/dia.2006.8.28

Pfutzner, A., Standl, E., Strotmann, H. J., Schulze, J., Hohberg, C., Lubben, G., et al. (2006). Association of highsensitive C-reactive protein with advanced stage beta-cell dysfunction and insulin resistance in patients with type 2 diabetes mellitus. Clin. Chem. Lab. Med. 44, 556-560. doi:10.1515/CCLM.2006.108

Picot, J., Jones, J., Colquitt, J. L., Gospodarevskaya, E., Loveman, E., Baxter, L., et al. (2009). The clinical effectiveness and cost-effectiveness of bariatric (weight loss) surgery for obesity: a systematic review and economic evaluation. Health Technol. Assess. 13, 215-357. doi:10.3310/hta13410

Piestrzeniewicz, K., Luczak, K., Komorowski, J., Maciejewski, M., Jankiewicz-Wika, J., and Goch, J. H. (2008). Resistin increases with obesity and atherosclerotic risk factors in patients with myocardial infarction. Metab. Clin. Exp. 57, 488-493. doi:10.1016/j.metabol. 2007.11.009

Poitou, C., Coussieu, C., Rouault, C., Coupaye, M., Cancello, R., Bedel, J. F., et al. (2006). Serum amyloid A: a marker of adiposityinduced low-grade inflammation but not of metabolic status.
Obesity (Silver Spring) 14, 309-318. doi:10.1038/oby.2006.40

Pradhan, A. D., Cook, N. R., Buring, J. E., Manson, J. E., and Ridker, P. M. (2003). C-reactive protein is independently associated with fasting insulin in nondiabetic women. Arterioscler. Thromb. Vasc. Biol. 23, 650-655. doi:10. 1161/01.ATV.0000065636.15310.9C

Qasim, A., Mehta, N. N., Tadesse, M. G., Wolfe, M. L., Rhodes, T., Girman, C., et al. (2008). Adipokines, insulin resistance, and coronary artery calcification. $J$. Am. Coll. Cardiol. 52, 231-236. doi:10.1016/j.jacc.2008.04.016

Queipo-Ortuño, M. I., Escoté, X., Ceperuelo-Mallafré, V., GarridoSanchez, L., Miranda, M., Clemente-Postigo, M., et al. (2012). FABP4 dynamics in obesity: discrepancies in adipose tissue and liver expression regarding circulating plasma levels. PLoS ONE. 7:e48605. doi:10.1371/journal.pone.0048605

Quinn, P. G., and Yeagley, D. (2005). Insulin regulation of PEPCK gene expression: a model for rapid and reversible modulation. Curr. Drug Targets Immune Endocr. Metabol. Disord. 5, 423-437. doi:10.2174/156800805774912962

Rasouli, N., and Kern, P. A. (2008). Adipocytokines and the metabolic complications of obesity. J. Clin. Endocrinol. Metab. 93(11 Suppl. 1), S64-73. doi:10.1210/jc.2008-1613

Reinehr, T., Woelfle, J., and Roth, C. L. (2011). Lack of association between apelin, insulin resistance, cardiovascular risk factors, and obesity in children: a longitudinal analysis. Metab. Clin. Exp. 60, 1349-1354. doi:10.1016/j.metabol. 2011.02.005

Retnakaran, R., Youn, B. S., Liu, Y., Hanley, A. J., Lee, N. S., Park, J. W., et al. (2008). Correlation of circulating full-length visfatin (PBEF/NAMPT) with metabolic parameters in subjects with and without diabetes: a cross-sectional study. Clin. Endocrinol. (Oxf) 69, 885-893. doi:10.1111/j.13652265.2008.03264.x

Rull, A., Camps, J., Alonso-Villaverde, C., and Joven, J. (2010). Insulin resistance, inflammation, and obesity: role of monocyte chemoattractant protein-1 (or CCL2) in the regulation of metabolism. Mediators Inflamm. 2010:326580. doi:10.1155/2010/326580. [Epub ahead of print].

Sandeep, S., Velmurugan, K., Deepa, R., and Mohan, V. (2007a). Serum visfatin in relation to visceral fat, obesity, and type 2 diabetes mellitus in Asian Indians. Metab. Clin. Exp. 56, 565-570. doi:10.1016/j.metabol.2006.12.005

Sandeep, S., Velmurugan, K., Deepa, R., and Mohan, V. (2007b). Serum visfatin in relation to visceral fat, obesity, and type 2 diabetes mellitus in Asian Indians. Metab. Clin. Exp. 56, 565-570. doi:10.1016/j.metabol.2006.12.005

Sentinelli, F., Romeo, S., Arca, M. Filippi, E., Leonetti, F., Banchieri, M., et al. (2002). Human resistin gene, obesity, and type 2 diabetes: mutation analysis and population study. Diabetes 51, 860-862. doi:10.2337/diabetes.51.3.860

Siddle, K. (2011). Signalling by insulin and IGF receptors: supporting acts and new players. J. Mol. Endocrinol. 47, R1-10. doi:10.1530/JME-110022

Sidhu, J. S., Cowan, D., and Kaski, J. C. (2003). The effects of rosiglitazone, a peroxisome proliferatoractivated receptor-gamma agonist, on markers of endothelial cell activation, C-reactive protein, and fibrinogen levels in non-diabetic coronary artery disease patients. $J$ Am. Coll. Cardiol. 42, 1757-1763. doi:10.1016/j.jacc.2003.04.001

Singla, P., Bardoloi, A., and Parkash, A. A. (2010). Metabolic effects of obesity: a review. World J. Diabetes 1 , 76-88. doi:10.4239/wjd.v1.i3

Sjostrom, L., Lindroos, A. K., Peltonen, M., Torgerson, J., Bouchard, C., Carlsson, B., et al. (2004). Lifestyle, diabetes, and cardiovascular risk factors 10 years after bariatric surgery. N. Engl. J. Med. 351, 2683-2693. doi:10.1056/NEJMoa035622

Soriguer, F., Garrido-Sanchez, L., Garcia-Serrano, S., Garcia-Almeida, J. M., Garcia-Arnes, J., Tinahones, F. J., et al. (2009). Apelin levels are increased in morbidly obese subjects with type 2 diabetes mellitus. Obes. Surg. 19, 1574-1580. doi:10.1007/s11695-009-9955-y

Spector, D., and Shikora, S. (2010). Neuro-modulation and bariatric surgery for type 2 diabetes mellitus. Int. J. Clin. Pract. Suppl. 166, 53-58. doi:10.1111/j.17421241.2009.02279.x

Spivak, H., Hewitt, M. F., Onn, A., and Half, E. E. (2005). Weight loss and improvement of obesity-related illness in 500 U.S. patients following laparoscopic adjustable gastric banding procedure. Am. J. Surg. 189, 27-32. doi:10.1016/j.amjsurg.2004.06.038

Steppan, C. M., Bailey, S. T., Bhat, S., Brown, E. J., Banerjee, R.
R., Wright, C. M., et al. (2001). The hormone resistin links obesity to diabetes. Nature 409, 307-312. doi:10.1038/35053000

Steppan, C. M., and Lazar, M. A. (2002). Resistin and obesity-associated insulin resistance. Trends Endocrinol. Metab. 13, 18-23. doi:10.1016/ S1043-2760(01)00522-7

Steppan, C. M., Wang, J., Whiteman, E. L., Birnbaum, M. J., and Lazar, M. A. (2005). Activation of SOCS-3 by resistin. Mol. Cell. Biol. 25, 1569-1575. doi:10.1128/ MCB.25.4.1569-1575.2005

Strader, A. D. (2006). Ileal transposition provides insight into the effectiveness of gastric bypass surgery. Physiol. Behav. 88, 277-282. doi:10.1016/j.physbeh.2006.05.034

Strader, A. D., Vahl, T. P., Jandacek, R. J., Woods, S. C., D'Alessio, D. A., and Seeley, R. J. (2005). Weight loss through ileal transposition is accompanied by increased ileal hormone secretion and synthesis in rats. Am. J. Physiol. Endocrinol. Metab. 288, E447-453. doi:10.1152/ajpendo.00153.2004

Suleymanoglu, S., Tascilar, E., Pirgon, O., Tapan, S., Meral, C., and Abaci, A. (2009). Vaspin and its correlation with insulin sensitivity indices in obese children. Diabetes Res. Clin. Pract. 84, 325-328. doi:10.1016/j.diabres. 2009.03.008

Sun, G., Bishop, J., Khalili, S., Vasdev, S., Gill, V., Pace, D., et al. (2007). Serum visfatin concentrations are positively correlated with serum triacylglycerols and down-regulated by overfeeding in healthy young men. Am. J. Clin. Nutr. 85, 399-404.

Sweeney, T. E., and Morton, J. M. (2013). The human gut microbiome: a review of the effect of obesity and surgically induced weight loss. JAMA Surg. doi:10.1001/jamasurg.2013.5. [Epub ahead of print].

Tan, B. K., Chen, J., Brown, J., Adya, R., Ramanjaneya, M., Menon, V., et al. (2009). In vivo and ex vivo regulation of visfatin production by leptin in human and murine adipose tissue: role of mitogen-activated protein kinase and phosphatidylinositol 3-kinase signaling pathways. Endocrinology 150, 3530-3539. doi:10.1210/en.2008-1655

Tarantino, G. and Caputi, A. (2011). JNKs, insulin resistance and inflammation: a possible link between NAFLD and coronary artery disease. World $J$. Gastroenterol. 17, 3785-3794. doi:10.3748/wjg.v17.i33.3785 
Thompson, A. M., Zhang, Y., Tong, W., Xu, T., Chen, J., Zhao, L., et al. (2011). Association of obesity and biomarkers of inflammation and endothelial dysfunction in adults in Inner Mongolia, China. Int. J. Cardiol. 150, 247-252. doi:10.1016/j.ijcard.2010.04.011

Tilg, H., and Moschen, A. R. (2006). Adipocytokines: mediators linking adipose tissue, inflammation and immunity. Nat. Rev. Immunol. 6, 772-783. doi:10.1038/nri1937

Tilg, H., and Moschen, A. R. (2008). Inflammatory mechanisms in the regulation of insulin resistance. Mol. Med. 14, 222-231. doi:10.2119/2007-00119.Tilg

Tokunaga, A., Miura, A., Okauchi, Y., Segawa, K., Fukuhara, A., Okita, K., et al. (2008). The-1535 promoter variant of the visfatin gene is associated with serum triglyceride and HDL-cholesterol levels in Japanese subjects. Endocr. J. 55, 205-212. doi:10.1507/endocrj.K07E-039

Toruner, F., Altinova, A. E., Akturk, M., Kaya, M., Arslan, E., Bukan, N., et al. (2010). The relationship between adipocyte fatty acid binding protein4, retinol binding protein-4 levels and early diabetic nephropathy in patients with type 2 diabetes. Diabetes Res. Clin. Pract. 91, 203-207. doi:10.1016/j.diabres.2010.11.011

Trayhurn, P. (2005). Adipose tissue in obesity - an inflammatory issue. Endocrinology 146, 1003-1005. doi:10.1210/en.2004-1597

Trayhurn, P. (2007). Adipocyte biology. Obes. Rev. 8(Suppl. 1), 41-44. doi:10.1111/j.1467789X.2007.00316.x

Tschoner, A., Sturm, W., Engl, J., Kaser, S., Laimer, M., Laimer, E., et al. (2008). Retinol-binding protein 4, visceral fat, and the metabolic syndrome: effects of weight loss. Obesity (Silver Spring) 16, 2439-2444. doi:10.1038/oby.2008.391

Tzanavari, T., Giannogonas, P., and Karalis, K. P. (2010). TNF-alpha and obesity. Curr. Dir. Autoimmun. 11, 145-156. doi:10.1159/000289203

van Hout, G. C., Jakimowicz, J. J., Fortuin, F. A., Pelle, A. J., and van Heck, G. L. (2007). Weight loss and eating behavior following vertical banded gastroplasty. Obes. Surg. 17, 1226-1234. doi:10.1007/s11695007-9205-0
Vazquez, L. A., Pazos, F., Berrazueta, J. R., Fernandez-Escalante, C., GarciaUnzueta, M. T., Freijanes, J., et al. (2005). Effects of changes in body weight and insulin resistance on inflammation and endothelial function in morbid obesity after bariatric surgery. J. Clin. Endocrinol. Metab. 90, 316-322. doi:10.1210/jc.2003032059

von Eynatten, M., Lepper, P. M., Liu, D., Lang, K., Baumann, M., Nawroth, P. P., et al. (2007). Retinol-binding protein 4 is associated with components of the metabolic syndrome, but not with insulin resistance, in men with type 2 diabetes or coronary artery disease. Diabetologia 50, 1930-1937. doi:10.1007/s00125007-0743-8

Wada, J. (2008). Vaspin: a novel serpin with insulin-sensitizing effects. Expert Opin. Investig. Drugs 17, 327-333. doi:10.1517/ 13543784.17.3.327

Wang, Y., Sullivan, S., Trujillo, M., Lee, M. J., Schneider, S. H., Brolin, R. E., et al. (2003). Perilipin expression in human adipose tissues: effects of severe obesity, gender, and depot. Obes. Res. 11, 930-936. doi:10.1038/oby.2003.128

Wang, Z., and Nakayama, T. (2010). Inflammation, a link between obesity and cardiovascular disease. Mediators Inflamm. 2010, 535918. doi:10.1155/2010/535918

Wolf, G. (2004). Insulin resistance and obesity: resistin, a hormone secreted by adipose tissue. Nutr. Rev. 62, 389-394. doi:10.1111/j.17534887.2004.tb00009.x

Wolf, G. (2007). Serum retinolbinding protein: a link between obesity, insulin resistance, and type 2 diabetes. Nutr. Rev. 65, 251-256. doi:10.1111/j.17534887.2007.tb00302.x

Wolfe, B. E., Jimerson, D. C., Orlova, C., and Mantzoros, C. S. (2004). Effect of dieting on plasma leptin, soluble leptin receptor, adiponectin and resistin levels in healthy volunteers. Clin. Endocrinol. (Oxf.) 61, 332-338. doi:10.1111/j.13652265.2004.02101.x

Yamamoto, T., Habata, Y., Matsumoto, Y., Yasuhara, Y., Hashimoto, T., Hamajyo, H., et al. (2011). Apelin-transgenic mice exhibit a resistance against diet-induced obesity by increasing vascular mass and mitochondrial biogenesis in skeletal muscle. Biochim. Biophys. Acta 1810, 853-862. doi:10.1016/j.bbagen.2011.05.004

Yan, E., Ko, E., Luong, V., Wang, H. J., Romanova, M., and Li, Z. (2008). Long-term changes in weight loss and obesity-related comorbidities after Roux-en-Y gastric bypass: a primary care experience. Am. J. Surg. 195, 94-98. doi:10.1016/j.amjsurg.2007.01.036

Yang, Q., Graham, T. E., Mody, N., Preitner, F., Peroni, O. D., Zabolotny, J. M., et al. (2005). Serum retinol binding protein 4 contributes to insulin resistance in obesity and type 2 diabetes. Nature 436, 356-362. doi:10.1038/ nature03711

Yao-Borengasser, A., Varma, V., Bodles, A. M., Rasouli, N., Phanavanh, B., Lee, M. J., et al. (2007). Retinol binding protein 4 expression in humans: relationship to insulin resistance, inflammation, and response to pioglitazone. J. Clin. Endocrinol. Metab. 92, 2590-2597. doi:10.1210/ jc. 2006-0816

Ye, Y., Hou, X. H., Pan, X. P., Lu, J. X., and Jia, W. P. (2009). Serum vaspin level in relation to postprandial plasma glucose concentration in subjects with diabetes. Chin. Med. J. 122, 2530-2533.

Yermilov, I., McGory, M. L., Shekelle, P. W., Ko, C. Y., and Maggard, M. A. (2009). Appropriateness criteria for bariatric surgery: beyond the NIH guidelines. Obesity (Silver Spring) 17, 1521-1527. doi:10.1038/oby.2009.78

Youn, B. S., Kloting, N., Kratzsch, J., Lee, N., Park, J. W., Song, E. S., et al. (2008). Serum vaspin concentrations in human obesity and type 2 diabetes. Diabetes 57, 372-377. doi:10.2337/db07-1045

Yu, S., Zhang, Y., Li, M. Z., Xu, H., Wang, Q., Song, J., et al. (2012). Chemerin and apelin are positively correlated with inflammation in obese type 2 diabetic patients. Chin. Med. J. (Engl.) 125, 3440-3444.

Yudkin, J. S. (2007). Inflammation, obesity, and the metabolic syndrome. Horm. Metab. Res. 39, 707-709. doi:10.1055/s-2007-985898

Yue, P., Jin, H., Aillaud, M., Deng, A. C., Azuma, J., Asagami,
T., et al. (2010). Apelin is necessary for the maintenance of insulin sensitivity. Am. J. Physiol. Endocrinol. Metab. 298, E59-67. doi:10.1152/ajpendo.00385.2009

Zeyda, M., and Stulnig, T. M. (2009). Obesity, inflammation, and insulin resistance - a minireview. Gerontology 55, 379-386. doi:10.1159/000212758

Zhang, H., DiBaise, J. K., Zuccolo, A., Kudrna, D., Braidotti, M., Yu, Y., et al. (2009). Human gut microbiota in obesity and after gastric bypass. Proc. Natl. Acad. Sci. U.S.A. 106, 2365-2370. doi:10.1073/pnas.0812600106

Zhou, Y., Liu, B. L., Liu, K., Tang, N., Huang, J., An, Y., et al. (2008). Establishment of the insulin resistance induced by inflammatory response in 3T3-L1 preadipocytes cell line. Inflammation 31, 355-364. doi:10.1007/s10753-008-9086-y

Zhu, S., Sun, F., Li, W., Cao, Y., Wang, C., Wang, Y., et al. (2011). Apelin stimulates glucose uptake through the PI3K/Akt pathway and improves insulin resistance in 3T3L1 adipocytes. Mol. Cell. Biochem. 353, 305-313. doi:10.1007/s11010011-0799-0

Conflict of Interest Statement: The authors declare that the research was conducted in the absence of any commercial or financial relationships that could be construed as a potential conflict of interest.

Received: 01 April 2013; accepted: 23 May 2013; published online: 10 June 2013.

Citation: Goktas Z, Moustaid-Moussa $N$, Shen $C-L$, Boylan $M, M o H$ and Wang $S$ (2013) Effects of bariatric surgery on adipokine-induced inflammation and insulin resistance. Front. Endocrinol. 4:69. doi: 10.3389/fendo.2013.00069 This article was submitted to Frontiers in Diabetes, a specialty of Frontiers in Endocrinology.

Copyright (C) 2013 Goktas, MoustaidMoussa, Shen, Boylan, Mo and Wang. This is an open-access article distributed under the terms of the Creative Commons Attribution License, which permits use, distribution and reproduction in other forums, provided the original authors and source are credited and subject to any copyright notices concerning any third-party graphics etc. 